\title{
Don't Take Away My P: Phosphatases as Therapeutic Targets in Huntington's Disease
}

\author{
Ana Saavedra1,2,3, Jordi Alberch1,2,3 and Esther Pérez-Navarro1,2,3 \\ ${ }^{1}$ Departament de Biologia Cellular, Immunologia i Neurociències, \\ Facultat de Medicina, Universitat de Barcelona, Barcelona, \\ 2Institut d'Investigacions Biomèdiques August Pi i Sunyer (IDIBAPS), Barcelona, \\ ${ }^{3}$ Centro de Investigación Biomédica en Red sobre, \\ Enfermedades Neurodegenerativas (CIBERNED),
}

Spain

\section{Introduction}

The molecular bases that account for the preferential neurodegeneration of striatal mediumsized spiny neurons (MSNs) in Huntington's Disease (HD) are still unknown, and different mechanisms have been proposed to contribute to the neurodegenerative process. These include mitochondrial dysfunction and metabolic impairment, transcriptional dysregulation, altered expression of trophic factors, dopamine toxicity, oxidative stress, and changes in autophagy, and huntingtin (htt) phosphorylation. In addition, excitotoxicity through the overactivation of N-methyl-D-aspartate (NMDA) receptors (NMDARs) has also been proposed to contribute to the preferential loss of these neurons (for review see Ehrnhoefer et al., 2011; Jin \& Johnson, 2010; Perez-Navarro et al., 2006; Renna et al., 2010; Rosenstock et al., 2010; Weir et al., 2011).

Some of these mechanisms are controlled by the attachment/removal of phosphate groups through the action of protein kinases and protein phosphatases, respectively. Therefore, alterations in their levels/activity in the presence of mutant htt (mhtt) can impact on cell survival.

Htt is expressed in almost all tissues, has a widespread distribution in the brain, its expression levels are similar in control individuals and in HD patients, with no evidence of increased htt expression in the brain regions most affected in HD (reviewed by Han et al., 2010). These evidences indicate that differences in mhtt expression do not contribute to the increased vulnerability of MSNs in HD. Conversely, several cell-type specific features including morphological, biochemical, and functional characteristics might play a role in rendering MSNs more vulnerable to the toxic effects of mhtt (Han et al., 2010). In this line, it is relevant in context of the present review to mention that the phosphatases calcineurin (also known as protein phosphatase 2B - PP2B) (Goto et al., 1987) and striatal-enriched protein tyrosine phosphatase (STEP) (Lombroso et al., 1991) are enriched in MSNs, suggesting that variations in their expression levels/activity can impact seriously in the function and viability of these neurons. 
Here, we will revisit the excitotoxic hypothesis in HD through the phosphatase point of view, and we will also pay attention to the importance of phosphorylation in reducing the toxicity of mhtt. We will discuss the results obtained in both exon-1 and full-length HD models, and we will integrate the potential contribution of an imbalance between the activity of phosphatases and kinases to HD pathophysiology.

\subsection{Excitotoxicity}

Glutamate, the major excitatory neurotransmitter in the central nervous system (CNS), is important for neural development, synaptic plasticity, and learning and memory under physiological conditions. Dysregulation of glutamate levels and/or glutamate receptor activity can result in an overstimulation of glutamate receptors leading to cell death via excitotoxicity (Olney, 1969). In HD, excitotoxicity induced by overactivation of NMDARs has been proposed to explain the preferential neurodegeneration of MSNs (reviewed by Fan \& Raymond, 2007; Milnerwood \& Raymond, 2010; Perez-Navarro et al., 2006). Functional NMDARs are tetrameric structures (Laube et al., 1998) composed of two NR1 and at least two NR2 subunits (Ozawa et al., 1998), and the striatum is enriched in NR2B compared with other NR2 subunits (Landwehrmeyer et al., 1995). The presence of mhtt in striatal neurons leads to a number of alterations that can explain changes in the susceptibility to excitotoxicity. These include: (1) Selective increase of the current flowing through NMDARs comprising NR1/NR2B subunits (Zeron et al., 2001, 2002); (2) Changes in NMDAR scaffolding proteins (Jarabek et al., 2004; Sun et al., 2001; Torres-Peraza et al., 2008); (3) Altered phosphorylation of NMDAR subunits (Jarabek et al., 2004; Song et al., 2003) and (4) Imbalance between synaptic and extra-synaptic NMDARs (Milnerwood et al., 2010; Okamoto, 2009). In addition to alterations at the level of NMDARs, mhtt also alters intracellular mechanisms regulated by NMDAR stimulation, such as the activity of kinases and phosphatases. Calcineurin, PP1, PP2A, and STEP are phosphatases regulated by NMDARs stimulation (Figure 1) whose levels/activity have been shown to be altered in neurons expressing exon-1 or full-length mhtt (Table 1).

\subsection{Phosphorylation of htt}

Htt has several known sites of phosphorylation, all of them less phosphorylated in the mutant than in the wild-type protein (reviewed by Ernhoefer et al., 2011). Among the htt phosphorylation sites identified, serine 421 (Ser421) is the most studied and thus, the best characterized. This site can be phosphorylated by Akt (Humbert et al., 2002) and serum and glucocorticoid-induced kinase (SGK) (Rangone et al., 2004), whereas calcineurin (Pardo et al., 2006; Pineda et al., 2009), PP1 and PP2A (Metzler et al., 2010) dephosphorylate it. Until now, phosphatases known to regulate htt phosphorylation at Ser421 have been shown to be altered in HD models (Table 1). Phosphorylation of Ser421 regulates htt's toxicity (Humbert et al., 2002; Pardo et al., 2006), htt's role in vesicle transport (Colin et al., 2008; Pineda et al., 2009; Zala et al., 2008), and htt cleavage by caspases (Metzler et al., 2010; Warby et al., 2009). In addition, phosphorylation of htt and mhtt at Ser421 is significantly reduced in neurons after excitotoxic stimulation of NMDARs (Metzler et al., 2010) (Figure 1). Moreover, there are other Ser and threonine (Thr) residues of htt that can be phosphorylated, and all of them regulate its toxicity. Most of the kinases that phosphorylate these sites have been identified, and include IKK (Thompson et al., 2009), cyclin-dependent kinase 5 (Cdk5) (Anne et al., 
2007; Luo et al., 2005), ERK1 (Schilling et al., 2006), and CK2 (Atwal et al., 2011). In contrast, the phosphatases acting on these residues are still unknown (reviewed by Ernhoefer et al., 2011).

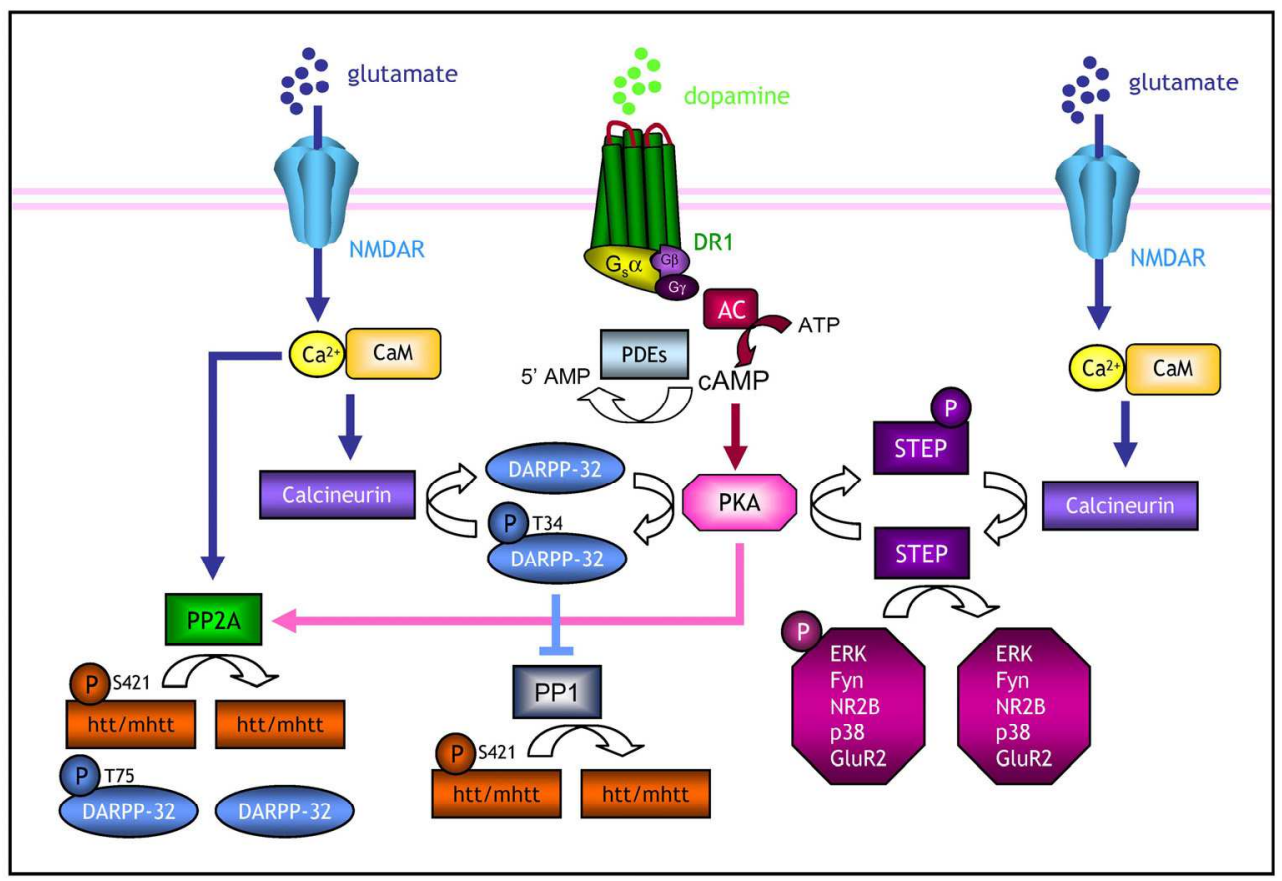

Fig. 1. Regulation of phosphatases in striatal neurons by NMDAR and dopamine D1 receptor (DR1) stimulation. Stimulation of NMDARs activates PP2A and calcineurin, which in turn will activate STEP and PP1. DR1 stimulation activates PP2A, and indirectly blocks PP1 activity. Several pathways and targets have been omitted for simplification. PDEs: Phosphodiesterases; AC: Adenylyl cyclase; PKA: cAMP-dependent protein kinase; CaM: calmodulin; DARPP-32: dopamine- and cAMP-regulated phosphoprotein of $32 \mathrm{kDa}$

\section{Ser/Thr phosphatases}

Ser/Thr phosphatases catalyze dephosphorylation reactions on phospho-Ser and phosphoThr residues. They are classified into three families: protein phosphatase $\mathrm{Mg}^{2+}$-activated (PPM), phosphoprotein phosphatases (PPPs) and the aspartate-based phosphatases represented by FCP/SCP (TFIIF-associating component of RNA polymerase II CTD phosphatase/small CTD phosphatase). The PPM family includes PP2C, pyruvate dehydrogenase phosphatase, and PP2C-“like" phosphatases, and the major phosphatases in the PPP family are PP1, PP2A and calcineurin (reviewed by McConnell \& Wadzinski, 2009). PP1, PP2A and calcineurin are composed of catalytic and regulatory subunits, whereas PP2C exists as a monomer devoid of regulatory subunits. In the brain, the activity of these phosphatases is regulated by the regulatory subunit, interacting partners, scaffolding proteins and/or specific endogenous activators/inhibitors (reviewed by Gee \& Mansuy, 
2005). These phosphatases are implicated in the regulation of excitotoxicity, synaptic plasticity and cell survival, and are altered in neurodegenerative disorders such as Alzheimer's Disease (Ducruet et al., 2005; Iqbal \& Grundke-Iqbal, 2007; F. Liu et al., 2006; Tian \& Wang, 2002), Parkinson's Disease (Lou et al., 2010; Wera \& Neyts, 1994) and HD (Metzler et al., 2010; Pineda et al., 2009; Saavedra et al., 2010; Xifro et al., 2008; 2009).

\begin{tabular}{|c|c|c|c|c|}
\hline $\begin{array}{c}\text { Type of } \\
\text { phosphatase }\end{array}$ & Phosphatase & Change & HD model & Reference \\
\hline \multirow{7}{*}{$\begin{array}{c}\text { Ser/Thr } \\
\text { Phosphatase }\end{array}$} & Calcineurin & Increased & $\begin{array}{l}\text { STHdh }{ }^{\mathrm{Q} 7 / \mathrm{Q}_{111}} \text { cells and } \\
\text { Hdh }{ }^{\mathrm{Q} 111 / \mathrm{Q} 111} \text { mice }\end{array}$ & $\begin{array}{l}\text { Xifro et al., } 2008 \\
\text { Pineda et al., } 2009\end{array}$ \\
\hline & & Reduced & R6/1; YAC128 & $\begin{array}{l}\text { Xifro et al., } 2009 \\
\text { Metzler et al., } 2010\end{array}$ \\
\hline & PHLPP1 & Reduced & $\begin{array}{l}\text { R6/1; R6/1:BDNF; R6/2; } \\
\text { Tet/HD94; HdhQ111/Q111 } \\
\text { and STHdh Q111/Q111 cells }\end{array}$ & Saavedra et al., 2010 \\
\hline & PHLPP2 & Unchanged/Reduced & $\mathrm{R} 6 / 1$ & $\begin{array}{c}\text { Rue et al., } \\
\text { unpublished }\end{array}$ \\
\hline & PP1 & $\begin{array}{l}\text { Unchanged } \\
\text { Reduced }\end{array}$ & $\begin{array}{l}\text { YAC128 } \\
\text { YAC128 }\end{array}$ & $\begin{array}{l}\text { Metzler et al., } 2010 \\
\text { Ehrnhoefer et al., } 2011\end{array}$ \\
\hline & PP2A & Unchanged & YAC128; R6/1 & $\begin{array}{l}\text { Metzler et al., } 2010 \\
\text { Saavedra et al., } 2010\end{array}$ \\
\hline & & Reduced & YAC128 & Ehrnhoefer et al., 2011 \\
\hline \multirow{3}{*}{$\begin{array}{c}\text { Tyr } \\
\text { Phosphatase }\end{array}$} & STEP & Decreased & $\begin{array}{c}\text { R6/1; R6/2; Tet/HD94; } \\
\text { HdhQ111/Q111 , primary } \\
\text { striatal neurons } \\
\text { overexpressing htt171- } \\
82 \mathrm{Q}\end{array}$ & $\begin{array}{l}\text { Saavedra et al., } 2011 \\
\text { Runne et al., } 2008\end{array}$ \\
\hline & $\begin{array}{l}\text { MKP1 and } \\
\text { MKP3 }\end{array}$ & Increased & $\begin{array}{l}\text { PC12 cells overexpressing } \\
\text { exon- } 1 \text { mhtt } 118 \mathrm{Q}\end{array}$ & Z. L. Wu et al., 2002 \\
\hline & MKР-2 & $\begin{array}{l}\text { Intracellular } \\
\text { redistribution }\end{array}$ & $\begin{array}{c}\text { HEK } 293 \text { cells } \\
\text { overexpressing mhtt } \\
\text { 138Q and NR1/NR2B }\end{array}$ & Fan et al., 2008 \\
\hline
\end{tabular}

Calcineurin (Xifro et al., 2009) and PHLPP1 (Saavedra et al., 2010) protein levels, and STEP mRNA levels (Hodges et al., 2006) are also decreased in the caudate/ putamen of HD patients. HEK: human embryonic kidney; Q: glutamine; Tet/HD94: conditional mouse model of HD

Table 1. Phosphatases altered in HD models. 


\subsection{Calcineurin}

Calcineurin is a Ser/Thr phosphatase activated by calcium/calmodulin, highly expressed in the brain, and abundant in the cytosol, and in pre-synaptic and post-synaptic terminals (Mansuy, 2003; Shibasaki et al., 2002). It is a heterodimer composed by a calmodulin-binding catalytic subunit, calcineurin A, and an intrinsic calcium-binding regulatory subunit, calcineurin B. The dependence on calcium distinguishes calcineurin from spontaneously active PP2A and from $\mathrm{Mg}^{2+}$-dependent PP2C. The binding of the calcium/calmodulin complex to calcineurin A with high affinity leads to the release of the auto-inhibitory domain from the active site and calcineurin activation. In addition to activation by calcium, calcineurin can also be activated by caspase- or calpain-mediated proteolysis, which originate a constitutively active form, insensitive to calcium/calmodulin (reviewed by A. Mukherjee \& Soto, 2011).

Calcineurin is the only calcium-dependent phosphatase present in neurons, which confers it an important role in the maintenance of cellular homeostasis, and in neuronal activity (Mansuy, 2003; Shibasaki et al., 2002). Calcineurin also modulates gene expression by the regulation of transcription factors such as the cAMP responsive element binding protein (CREB) and the nuclear factor of activated T-cell (NFAT) (reviewed by A. Mukherjee \& Soto, 2011).

Calcineurin is highly expressed in the striatum, and in particular in MSNs (Goto et al., 1987). The participation of calcineurin in neuronal death induced by insults that elevate intracellular calcium levels (Ankarcrona et al., 1996; Butcher et al., 1997; Dawson et al., 1993; Shamloo et al., 2005; Shibasaki \& McKeon 1995; Wood \& Bristow 1998; H. Y. Wu et al., 2004) suggests that this phosphatase might be a good candidate to participate in the excitotoxic events associated with HD.

The pro-apoptotic function of calcineurin has been linked to the dephosphorylation of selected substrates related to apoptosis, such as Bad (a pro-apoptotic Bcl-2 family member) (Springer et al., 2000; H. G. Wang et al., 1999), death-associated protein kinase (Shamloo et al., 2005; Xifro et al., 2008), cdk5 (Nishi et al., 2002) or transcription factors, such as NFAT (Beals et al., 1997). Importantly, calcineurin also dephosphorylates mhtt at Ser421 (Pardo et al., 2006). Consistent with the neuroprotective role of htt phosphorylation at Ser421 (Humbert et al., 2002; Rangone et al., 2004; Warby et al., 2005), inhibition of calcineurin activity in HD neuronal cells restores htt phosphorylation levels at Ser421, and prevents polyglutamine (polyQ)-mediated cell death of striatal neurons (Pardo et al., 2006). Moreover, inhibition of calcineurin by FK506 leads to sustained phosphorylation of mhtt at Ser421 and reestablishes BDNF transport in rat primary neuronal cultures expressing mhtt, and in mouse cortical neurons from HdhQ111/Q111 mice (Pineda et al., 2009). Recently, calcineurin has been shown to dephosphorylate the pro-fission dynamin related protein 1 (Cereghetti et al., 2008), which increases its mitochondrial translocation and activation, leading to mitochondrial fragmentation and contributing to the hypersensitivity of HD mitochondria to apoptosis (Costa et al., 2010). In fact, mitochondrial fragmentation can be prevented by genetic or pharmacological inhibition of calcineurin (Costa et al., 2010).

Studies using primary striatal cultures from YAC transgenic mice show that NMDAR stimulation produces a polyQ length-dependent increase in cell death (Shehadeh et al., 2006; Zeron et al., 2002). These observations were extended by our studies showing that 
STHdhQ111/Q111 cells are more susceptible to NMDA-mediated cell death than STHdhQ7/Q7 cells, a phenomenon related to higher calcineurin A protein levels and calcineurin activity in mhtt knock-in striatal cells than in wild-type cells (Xifro et al., 2008). Interestingly, although calcineurin protein levels are similar in mouse brains containing wild-type and mhtt, HdhQ111/Q111 and HdhQ111/Q7 mice have significantly higher levels of calcineurin activity in the cortex than $\mathrm{Hdh} \mathrm{Q}^{7} \mathrm{Q} 7$ mice (Pineda et al., 2009). In agreement with these reports showing increased calcineurin activity, the levels of the negative regulator of calcineurin RCAN1-1L are significantly down-regulated in HD brain samples (Ermak et al., 2009). Additionally, a dysregulation in the levels of cytosolic calcium, the calcineurin activator, was also reported in primary cultures from YAC128 mice (Tang et al., 2005). Calcineurin can play a toxic role in striatal cells expressing full-length mhtt at two different levels. High levels of calcineurin increase the susceptibility to excitotoxicity (Xifro et al., 2008) and, on the other hand, calcineurin can increase mhtt toxicity directly by dephosphorylation of its Ser421 (Ermak et al., 2009; Pardo et al., 2006; Pineda et al., 2009), or indirectly by regulating proteins that modulate mhtt toxicity, such as cdk5 (Luo et al., 2005) or calpain (Gafni et al., 2004).

Conversely, calcineurin A mRNA levels are decreased in human HD samples (Hodges et al., 2006). Similarly, in the striatum of R6 mouse models of HD, which express the exon- 1 mhtt fragment, calcineurin levels are lower than in the wild-type mice striatum (HernandezEspinosa \& Morton, 2006; Lievens et al., 2002; Luthi-Carter et al., 2000; Xifro et al., 2009). Interestingly, these mice are resistant to excitotoxicity (Hansson et al., 1999, 2001; TorresPeraza et al., 2008). These findings suggest a dual regulation of calcineurin A expression during the progression of the disease, with high levels at early stages resulting in high susceptibility to excitotoxicity (Xifro et al., 2008), and low levels at end stages participating in the resistance to excitotoxic-induced cell death (Xifro et al., 2009) (Figure 2). Thus, it would be relevant to study whether this dual calcineurin regulation also occurs in fulllength mouse models of HD as YAC128 mice, which were reported to be more sensitive to excitotoxicity than controls at presymptomatic stages, but resistant to intrastriatal quinolinic acid (an NMDAR agonist) injection when signs of HD are obvious (Graham et al., 2009). Consistent with resistance to excitotoxicity (Graham et al., 2009), reduced calcineurin activity has been shown in the striatum of YAC128 mice at 12 months of age (Metzler et al., 2010).

Studies performed in in vivo models of HD confirm the important role played by calcineurin in the excitotoxic-mediated cell death of striatal neurons. Calcineurin inhibition in wild-type mice drastically reduces quinolinic acid-induced striatal cell death (Xifro et al., 2009). Moreover, calcineurin activation induced by intrastriatal quinolinic acid injection in R6/1 mice is lower than in wild-type mice (Xifro et al., 2009), which is consistent with R6/1 animals being resistant to excitotoxicity (Hansson et al., 1999, 2001).

However, the role of calcineurin in HD remains controversial as calcineurin inhibition has been reported to have protective (Costa et al., 2010; Ermak et al., 2009; Pardo et al., 2006; Pineda et al., 2009; Xifro et al., 2008) or worsening (Hernandez-Espinosa \& Morton, 2006) effects in HD models. The participation of reduced calcineurin activity caused by alteration of calcineurin A expression in the pathophysiology of HD, and in the excitotoxic resistance observed in exon-1 mouse models (Xifro et al., 2009), together with the finding that treatment with calcineurin inhibitors accelerates the progression of the disease in R6/2 mice (Hernandez-Espinosa \& Morton, 2006) suggest that decreased levels of calcineurin could 
result in striatal neuronal dysfunction affecting the onset of motor alterations. However, since both FK506 and cyclosporine A, that does not cross the blood-brain barrier, have the same negative effect (Hernandez-Espinosa \& Morton, 2006) the harmful effect of calcineurin inhibition reported in this study might be unrelated to the effect of these inhibitors in the CNS.

Taken together, these findings suggest calcineurin as an important therapeutic target for $\mathrm{HD}$, by its participation in excitotoxic events, as well as by its action on phosphorylated mhtt (Ser421) to increase toxicity.
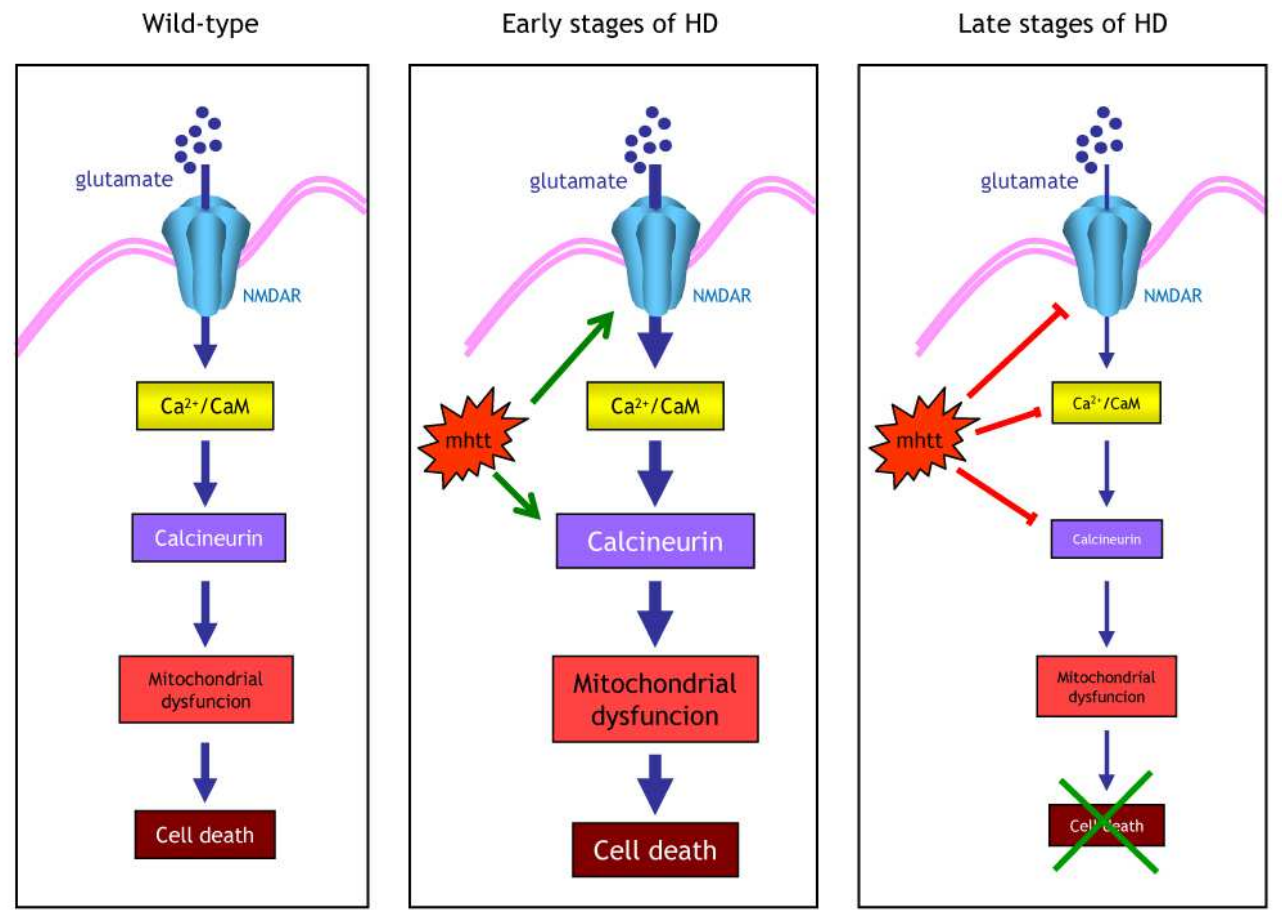

Fig. 2. Changes in striatal calcineurin levels during HD progression, and involvement in excitotoxicity. Results from Xifro et al. (2008) suggest that at early stages of HD calcineurin levels are increased and striatal neurons are more susceptible to NMDA-induced excitotoxicity. In contrast, at late stages, calcineurin levels are decreased and participate in the resistance of striatal neurons to NMDA-induced excitotoxicity (Xifro et al., 2009). CaM: calmodulin.

\subsection{Pleckstrin homology (PH) domain leucine-rich repeat protein phosphatase (PHLPP)}

PHLPPs constitute a subfamily within the PP2C phosphatase family. PHLPPs require $\mathrm{Mg}^{2+}$ and $\mathrm{Mn}^{2+}$ for their catalytic activity, and are not inhibited by traditional phosphatase inhibitors such as okadaic acid (Brognard et al., 2007; Gao et al., 2005). This family comprises three members: PHLPP1 $\alpha$, PHLPP1 $\beta$ and PHLPP2. PHLPP1 $\alpha$ and PHLPP1 $\beta$ are splice variants from the same gene but have different sizes, whereas PHLPP2 is a different gene product and has the same domain composition of PHLPP1 (Brognard et al., 2007). PHLPP1 
and PHLPP2 have an identical domain structure with a PH domain (sharing $63 \%$ amino identity) followed by a region of leucine-rich repeats, a PP2C phosphatase domain (sharing $58 \%$ amino identity) and a C terminal PDZ ligand. In addition, PHLPP1 $\beta$ and PHLPP2 contain a Ras-association domain preceding the PH domain (Brognard \& Newton, 2008).

PHLPPs are expressed in the majority of human tissues and are localized in different cellular compartments such as cytosol, nucleus and membrane (Brognard et al., 2007; Brognard \& Newton, 2008). In the CNS, PHLPP1 $\beta$ was the first identified as an mRNA that oscillated in a circadian rhythm-dependent manner in the suprachiasmatic nucleus (SCN) and was named SCOP (SCN circadian oscillatory protein) (Shimizu et al., 1999). PHLPP1 $\beta /$ SCOP is expressed in various brain regions with a relative enrichment in hippocampus and cerebellum (Shimizu et al., 1999). Its expression is highly concentrated in neurons, and is present in nuclear, mitochondrial and cytosolic fractions (Shimizu et al., 1999), as well as in membrane rafts (Shimizu et al., 2003). Recently, PHLPP1 $\alpha$ and PHLPP2 have been shown to be also expressed in hippocampal neurons (Jackson et al., 2009; 2010) with PHLPP1a as the most abundantly expressed in the adult (Jackson et al., 2010). Although PHLPP1 and 2 can be found in the cytosolic fraction, only PHLPP1a can be localized in the nucleus of hippocampal neurons (Jackson et al., 2010). In addition, we have detected PHLPP1a in the cortex and striatum of adult mice (Saavedra et al., 2010).

So far, the known substrates for PHLPPs are the kinases Akt (also known as protein kinase B), and protein kinase C (PKC). Akt, the first identified substrate of PHLPP (Gao et al., 2005), is a key regulator of a wide range of cellular processes including growth, proliferation, metabolism, cell cycle progression, and survival. Thus, altered Akt activity has been associated with cancer and other disease conditions such as diabetes and neurodegenerative diseases (Liao \& Hung, 2010). For its full catalytic activity, Akt requires phosphorylation at Thr308 in the activation loop and at Ser473 in the hydrophobic motif (Brazil \& Hemmings, 2001). Its activation depends on the PI3-kinase, which produces the lipid second messenger PtdIns-3, 4, 5-P3 (PIP3) that interacts with the PH domain of Akt and recruits the kinase to the plasma membrane (Sancak et al., 2008). Subsequently, the Thr308 residue is phosphorylated by membrane-localized 3-phosphoinositide-dependent protein kinase 1 (PDK1) (Alessi et al., 1997; Calleja et al., 2007) and the Ser473 residue is phosphorylated by mTORC2 (Sarbassov et al., 2005) (Figure 3). PHLPPs specifically dephosphorylate the hydrophobic motif of Akt, resulting in a decrease of its activity (Gao et al., 2005), whereas the Thr308 site is dephosphorylated by PP2A (Bayascas \& Alessi, 2005). PKC, the other PHLPPs substrate, consists in a Ser/Thr family of phosphorylating enzymes ubiquitously expressed and implicated in multiple cellular functions. There are 12 isoforms of PKC termed (1) calcium-dependent or classical PKCs, cPKCs (2) calcium-independent or novel PKCs, nPKCs, and (3) atypical PKCs, aPKCs (Amadio et al., 2006; Pearce et al., 2010). PKC isoforms, like Akt, are also activated by the phosphorylation of the activation segment and hydrophobic motif (Newton, 2003). PDK1 phosphorylates the activation segment (Dutil et al., 1998; Le Good et al., 1998), and there is increasing evidence that mTORC2 phosphorylates the hydrophobic motif of at least some isoforms (Sarbassov et al., 2004; Guertin et al., 2006). The phosphorylation of the hydrophobic motif regulates the amplitude of PKC signaling by controlling the stability of the kinase. Both PHLPP1 and PHLPP2 dephosphorylate the hydrophobic motif of conventional and novel PKC isoforms, but not atypical PKC isoforms (Gao et al., 2008). This dephosphorylation induces the degradation of PKC. Thus, depletion of PHLPP1 or PHLPP2 leads to a robust increase in PKC levels (Gao et al., 2008). 
Members of the AGC kinase family like p70S6K, SGK or p90RSK, which have hydrophobic phosphorylation motifs, are other potential substrates of PHLPPs (Brognard \& Newton, 2008). In addition to the dephosphorylation of Akt and PKC, PHLPP1 $\beta /$ SCOP negatively regulates the Ras-Raf-MEK-ERK pathway by interacting directly with Ras (Shimizu et al., 2003).

In the CNS, PHLPPs participate in the regulation of the circadian clock (Shimizu et al., 1999), learning and memory (Shimizu et al., 2007), and survival (Jackson et al., 2009; 2010; Saavedra et al., 2010). In HD, we have shown that PHLPP1a is reduced in cellular as well as in HD mouse models, and in the putamen of HD patients (Saavedra et al., 2010). STHdhQ111/Q111 cells display decreased levels of PHLPP1a compared with STHdhQ7/Q7 cells. Similarly, we detected reduced levels of PHLPP1a in the striatum of HdhQ111/Q111 mice (at 5 months of age), and also in the striatum of the exon- 1 mouse models R6/1 (from 12 to 30 weeks of age), R6/1:BDNF +/- (from 12 to 30 weeks of age), R6/2 (at 12 weeks of age) and Tet/HD94 (at 22 months of age). In addition, PHLPP1a levels are also decreased in the cortex and hippocampus of R6/1 mice at 12 and 30 weeks of age. PHLPP1 expression was regulated by mhtt at the transcriptional level since we also detected decreased PHLPP1 mRNA levels in the striatum of R6/1 mice (Saavedra et al., 2010). We speculated that the down-regulation of PHLPP1 mRNA levels could be related with decreased activity of the transcription factor NF-Y, since this transcription factor is sequestered in mhtt aggregates (Yamanaka et al., 2008). It has recently been shown that the expression of PHLPP is controlled by mammalian target of rapamycin (mTOR)-dependent protein translation in colon and breast cancer cells (J. Liu et al., 2011). Interestingly, mTOR activity is reduced in HD (Ravikumar et al., 2004). Thus, it is tempting to speculate that this mechanism could also be involved in the down-regulation of PHLPP1a levels. In good correlation with decreased levels of PHLPP1a in the striatum, we observed increased phosphorylation levels of Akt (Ser473) and of its targets GSK3 $\beta$ (Ser9) and FoxO (Ser256). Although PHLPP1a levels were down-regulated in the cortex and hippocampus of R6/1 mice we did not observe changes in pAkt (Ser473) levels indicating that a reduction of PHLPP1a levels may not be enough to increase pAkt (Ser473) levels in vivo (Saavedra et al., 2010). In addition, in the striatum of Tet/HD94 mice, we observed that after shutting-down the expression of mhtt, PHLPP1a protein levels returned to wild-type levels but pAkt (Ser473) up-regulation was only partially reduced (Saavedra et al., 2010). Taken together, these results suggest that increased levels of pAkt is a specific mechanism taking place in striatal neurons expressing mhtt, which could be the sum of increased activation of kinases that phosphorylate Akt and decreased levels of PHLPP1a. Since Akt activation is one of the main mechanisms to prevent neuronal death during injury (Chong et al., 2005), and many transgenic HD mouse models show little, if any, striatal cell death (Canals et al., 2004; Diaz-Hernandez et al., 2005; GarciaMartinez et al., 2007; Mangiarini et al., 1996; Martin-Aparicio et al., 2001), our results suggest that increased Akt activation could counteract mhtt toxicity.

In addition, we showed that decreased levels of PHLPP1a could help to maintain high levels of pAkt (Ser473) in R6/1 striatum after excitotoxicity, contributing to prevent cell death induced by NMDARs overstimulation (Saavedra et al., 2010).

Conversely, we found unchanged levels of PHLPP2 in the striatum in R6/1 mice at different stages of the disease $(8,12,20$ and 30 weeks of age), while cortical levels are decreased at 12 and 30 weeks of age. 

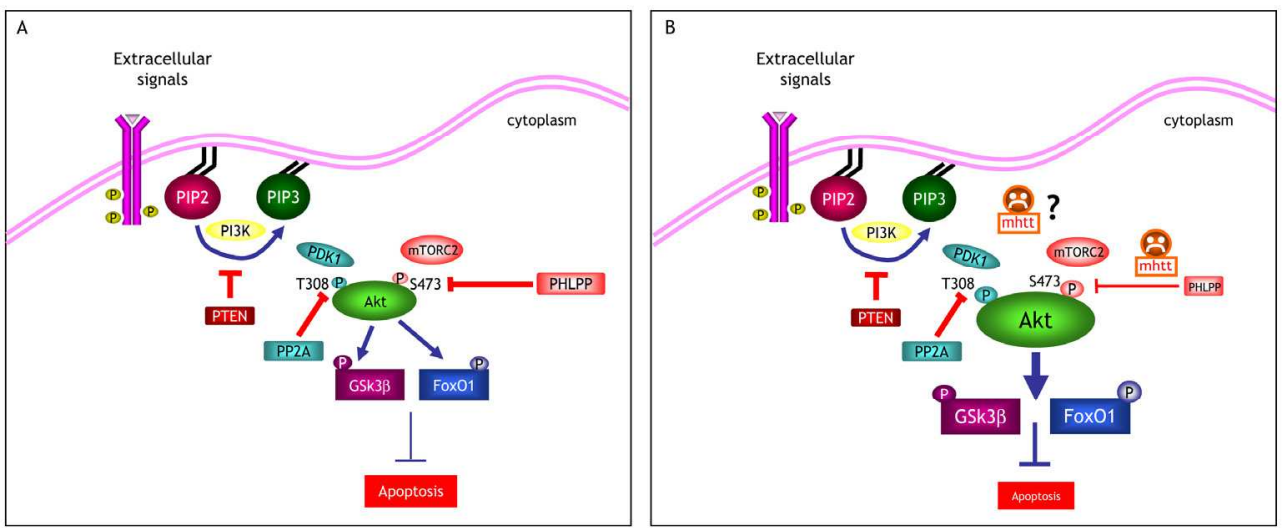

Fig. 3. PHLPP1a is down-regulated in HD striatum. (A) Scheme showing pathways that control Akt phosphorylation in wild-type cells. Akt is phosphorylated at Thr308 (T308) by PDK1 and dephosphorylated by PP2A, whereas the Ser473 residue (S473) is phosphorylated by mTORC2 and dephosphorylated by PHLPP. Once activated, Akt prevents apoptosis through the phosphorylation of several targets such as GSK3 $\beta$ and FoxO1. (B) Control of Akt phosphorylation in striatal cells expressing mhtt. In the presence of mhtt PHLPP1a levels are decreased and contribute to maintain high levels of Akt phosphorylated at S473 that through increased levels of phosphorylated GSK3 $\beta$ and FoxO1 may delay striatal cell death. Results obtained by analyzing different brain regions suggest that mhtt could also affect the activation of kinases that phosphorylate Akt in the striatum, but not in other brain regions (Saavedra et al., 2010).

\subsection{PP1 and PP2A}

PP1 and PP2A account for the majority of Ser/Thr phosphatase activity in mammalian cells, and are involved in diverse cellular processes such as cell growth and proliferation, development, DNA replication and repair, metabolism, neural signaling, and apoptosis. The activity of these two phosphatases can be blocked by okadaic acid and caliculin at different IC50 values (Sheppeck et al., 1997). The specific oligomeric composition of PP1 and PP2A holoenzyme is important to control their phosphatase activity. Functional PP1 enzyme consists of a catalytic subunit (PP1c) and a regulatory subunit (R subunit). The PP1c associates with more than 50 proteins that regulate substrate specificity and subcellular localization (Ceulemans \& Bollen, 2004; P.T. Cohen, 2002). The interaction of PP1c with its regulatory subunit can also influence substrate specificity. In addition, its activity is regulated by endogenous inhibitory proteins like inhibitor-1 (P. Cohen \& Nimmo, 1978), inhibitor-2 (Foulkes \& P. Cohen, 1980), CPI-17 (Eto et al., 1997), and DARPP-32 (Walaas \& Greengard, 1991), which is highly expressed in MSNs. PP2A exists in two forms: a core dimer and a heterotrimeric holoenzyme. The PP2A core dimer is composed by the scaffolding A subunit and the catalytic $\mathrm{C}$ subunit and associates with a regulatory $\mathrm{B}$ subunit to generate the heterotrimeric holoenzyme, which is the predominant form of PP2A in the cell. PP2A regulatory $B$ subunits are divided into four different families and play a crucial role in the subcellular localization of PP2A. They can also alter the overall shape of the catalytic subunit as well as enzyme kinetics (reviewed by McConnell \& Wadzinski, 2009; Shi, 2009). 
In the CNS, PP1 and PP2A dephosphorylate neurotransmitter receptors and proteins localized at the post-synaptic site, thus participating in the regulation of excitatory and inhibitory transmission. PP1 dephosphorylates CaMKII when bound to post-synaptic density, whereas soluble or synaptosomal CaMKII is deposphorylated by PP2A (Shields et al., 1985; Strack et al., 1997). In addition, both phosphatases regulate NMDARs-mediated synaptic currents in an activity-dependent manner (L. Y. Wang et al., 1994; Westphal et al., 1999). PP1 dephosphorylates GABA receptor subunits (X. Wang et al., 2002) and downregulates AMPA receptor activity and trafficking by dephosphorylation of the GluR1 subunit (reviewed by Mansuy \& Shenolikar, 2006). In addition, PP1 and PP2A activity can promote apoptosis (reviewed by Garcia et al., 2003; Klumpp \& Krieglstein, 2002). PP1 dephosphorylates the pro-apoptotic protein Bad with its consequent activation, and PP2A dephosphorylates the anti-apoptotic proteins Akt and Bcl-2 inactivating them. PP2A can also regulate the activity of a large number of kinases, such as ERK, PKA and p38 (reviewed by Millward et al., 1999), all of them important to neuronal survival and function.

Recently, the number of targets of PP1 and PP2A has been extended since both proteins dephosphorylate htt in situ and after excitotoxic stimulation of NMDARs (Metzler et al., 2010; see Figure 1). Metzler and colleagues (2010) showed that NMDARs overstimulation induces a decrease of phtt (Ser421) in primary neurons from wild-type and YAC128 transgenic mice. In addition, dephosphorylation of htt (Ser421) was also observed in YAC128 transgenic mice after quinolinic acid injection in the striatum. Dephosphorylation of htt after excitotoxicity seems to participate in the induction of cell death since blockade of PP1 and PP2A activity protects YAC128 striatal neurons from NMDA-induced cell death in vitro. Moreover, they showed that dopamine modulates htt phosphorylation in the striatum through the regulation of the PP1 inhibitor DARPP-32. These authors also observed a decrease in the PP1 substrate pCREB, which together with decreased levels of DARPP-32 in YAC128 striatum suggested an altered regulation of phosphatase activity in HD. However, they could not detect changes in the activity of PP1 and PP2A in YAC128 mice striatum. Although these results point to a role of htt dephosphorylation in excitotoxic-induced cell death in the striatum, it remains to be shown whether inhibition of PP1 and PP2A is also neuroprotective in vivo. In addition, it would be interesting to investigate whether dephosphorylation of mhtt takes place in the striatum of YAC128 mice when they are resistant to excitotoxicity. PP2A protein levels have also been analyzed in the striatum of R6/1 mice. Similarly to that observed in YAC128 mice striatum (Metzler et al., 2010), no changes in PP2A protein levels have been detected in R6/1 mouse striatum at 4, 8, 12, 16 and 30 weeks of age compared with their littermate controls (Saavedra et al., 2010).

\section{Tyrosine phosphatases}

Tyrosine (Tyr) phosphatases, encoded by about 107 genes in the human genome (Alonso et al., 2004; Andersen et al., 2004), have the ability to hydrolyze p-nitrophenyl phosphate, are inhibited by vanadate and are insensitive to okadaic acid. They are classified into three groups: (1) Cytoplasmic, (2) Receptor-like, and (3) Dual specificity phosphatases, which dephosphorylate Ser, Thr and Tyr residues that are in close proximity. The specificity of Tyr phosphatases is regulated by several molecular strategies such as preferential recognition of phosphopeptides, cell-type and organelle-specific expression, and assembly with other proteins (for review see S. Paul \& Lombroso, 2003; Z. Y. Zhang, 2002). These phosphatases 
play important roles in the development and function of the CNS (Ensslen-Craig \& Brady-Kalnay, 2004; S. Paul \& Lombroso, 2003), and have been suggested to function as neuroprotectants. STEP, the SH2-containing Tyr phosphatases SHP1 and SHP2, and protein Tyr phosphatase alpha are among the protective candidates. However, protein Tyr phosphatase alpha and phosphatase and tensin homolog deleted from chromosome 10 (PTEN) may also induce neurotoxicity (Gee \& Mansuy, 2005). Increased Tyr phosphorylation has been suggested to induce neuronal cell death in cerebral ischemia (Ohtsuki et al., 1996; R. Paul et al., 2001) and after epileptiform activity (Chun et al., 2004; Sanna et al., 2000). In addition, alterations in protein Tyr phosphatases are considered to be involved in the etiology of neural disorders such as Alzheimer's Disease (Kerr et al., 2006; Lee et al., 2004), Parkinson's Disease (Herradon \& Ezquerra, 2009) and HD (Saavedra et al., 2011; Z. L. Wu et al., 2002).

\subsection{STEP}

STEP, encoded by the Ptpn 5 gene, is a brain-specific Tyr phosphatase involved in neuronal signal transduction. STEP plays an important role in synaptic plasticity through the opposition to synaptic strengthening (Braithwaite et al., 2006a). Additionally, STEP has been implicated in susceptibility to cell death through the modulation of ERK1/2 signaling (Choi et al., 2007; Saavedra et al., 2011), while other studies suggest that STEP can play a role in neuroprotection through the regulation of the p38 pathway (Poddar et al., 2010; Xu et al., 2009). The mechanism underlying the ability of STEP to regulate both pro-survival and procell death pathways has been recently elucidated (Xu et al., 2009; see details below).

STEP is enriched in MSNs (Lombroso et al., 1991), and expressed at lower levels in the cortex, hippocampus and amygdala (Boulanger et al., 1995). STEP mRNA is alternatively spliced into several STEP isoforms (Bult et al., 1997; Sharma et al., 1995) that are differentially targeted to the post-synaptic density (Oyama et al., 1995), extra-synaptic and cytosolic compartments (Goebel-Goody et al., 2009; Xu et al., 2009). The major isoforms are $\mathrm{STEP}_{46}$, the cytosolic isoform, and $\mathrm{STEP}_{61}$, which is membrane-associated through the additional 172 amino acids in the N-terminus (Bult et al., 1997). Both isoforms are expressed in the striatum, whereas other brain regions only express STEP $_{61}$ (Boulanger et al., 1995).

STEP activity is regulated through phosphorylation/dephosphorylation of a Ser residue within its kinase interacting motif (KIM) domain. Stimulation of D1Rs activates PKA (Stoof \& Kebabian, 1981), which phosphorylates STEP thereby inactivating it (S. Paul et al., 2000) (Figure 1). In contrast, stimulation of NMDARs results in the dephosphorylation and activation of STEP through a calcineurin/PP1 pathway (S. Paul et al., 2003; Valjent et al., 2005) (Figure 1). Additionally, STEP activity is also regulated by proteolytic cleavage (Xu et al., 2009), ubiquitin-proteasome degradation (Kurup et al., 2010; S. Mukherjee et al., 2011; Xu et al., 2009), local translation (Y. Zhang et al., 2008), and oligomerization (Deb et al., 2011).

Once activated, STEP dephosphorylates the glutamate receptor subunits NR2B (Braithwaite et al., 2006b; Pelkey et al., 2002; Snyder et al., 2005) and GluR2 (Y. Zhang et al., 2008), leading to their endocytosis, and the kinases ERK1/2, p38 and Fyn, thereby controlling the duration of their signal (Munoz et al., 2003; Nguyen et al., 2002; S. Paul et al., 2003; Pulido et al., 1998) (Figure 1). 
The enrichment of STEP in MSNs, its role in the regulation of key substrates implicated in neuronal function, together with the fact that both dopaminergic and glutamatergic systems regulate STEP activity and are affected in HD patients and mouse models (Andre et al., 2010; Fan \& Raymond, 2007; Jakel \& Maragos, 2000) prompted us to study the possible role of STEP in the pathophysiology of HD (Saavedra et al., 2011). In fact, previous studies showed decreased mRNA levels of STEP in the caudate nucleus and cortex of HD patients (Hodges et al., 2006), in the striatum of R6 mice (Desplats et al., 2006; Luthi-Carter et al., 2000), and in primary striatal neurons overexpressing htt171-82Q (Runne et al., 2008). Our results show that R6/1 mice display reduced STEP protein levels in the striatum and cortex, and increased phosphorylation levels in the striatum, cortex and hippocampus. R6/2, Tet/HD94 and HdhQ7/Q111 mice striatum also displays decreased STEP protein and increased STEP phosphorylation levels (Saavedra et al., 2011). The early increase in striatal STEP phosphorylation levels correlates with a dysregulation of the PKA pathway that together with decreased calcineurin activity at later stages further contributes to an enhancement of STEP inactivation. Accordingly, the levels of phosphorylated ERK2 and p38, two targets of STEP, are increased in R6/1 mice striatum at advanced stages of the disease (Saavedra et al., 2011).

HD mouse models develop resistance to excitotoxicity (Graham et al., 2009; Hansson et al., 1999, 2001; Jarabek et al., 2004; Torres-Peraza et al., 2008), and reduced levels of calcineurin expression and activity can contribute to this phenomenon (Xifro et al., 2009). Stimulation of NMDARs activates STEP in a calcineurin-dependent manner (S. Paul et al., 2003), and disruption of STEP activity has been shown to lead to the activation of ERK1/2 signaling and to the attenuation of excitotoxic-induced cell death in the hippocampus (Choi et al., 2007). Therefore, we wondered whether STEP acts as a calcineurin target after an excitotoxic stimulus to the striatum thereby contributing to the resistance to excitotoxicity observed in HD mouse models. After intrastriatal quinolinic acid injection, we observed higher and unaltered pSTEP levels, and more sustained ERK signaling in R6/1 than in wild-type mice suggesting that STEP inactivation could mediate neuroprotection in R6/1 striatum (Saavedra et al., 2011). These findings are consistent with lower calcineurin activation which, importantly, correlates with reduced cell death in R6/1 mice striatum after quinolinic acid injection (Xifro et al., 2009). In agreement with a protective role for STEP inactivation, blockade of STEP activity with FK-506 (an inhibitor of calcineurin) allows ERK activation and confers protection to hilar interneurons of the hippocampus against excitotoxicity (Choi et al., 2007), and intrastriatal infusion of TAT-STEP, a cell-permeable form, increases quinolic acid-induced cell death in the striatum (Saavedra et al., 2011). Conversely, low striatal STEP levels and activity (increased pSTEP levels) in R6/1 mice can contribute to their reduced vulnerability to excitotoxicity (Saavedra et al., 2011).

Activation of extra-synaptic NMDARs in primary cortical neurons leads to calpainmediated cleavage of $\mathrm{STEP}_{61}$. This prevents STEP from binding to its substrates and contributes to the selective activation of extra-synaptically concentrated p38 (Xu et al., 2009). In contrast, synaptic NMDAR stimulation leads to the ubiquitination and degradation of STEP $_{61}$ and ERK1/2 activation (Xu et al., 2009). We did not observe STEP $_{61}$ cleavage or p38 activation which, together with ERK2 activation, suggests a preferential stimulation of synaptic NMDARs in our model (Saavedra et al., 2011). This is relevant because an imbalance between synaptic and extra-synaptic NMDARs has been shown to occur in YAC128 mice (Milnerwood et al., 2010; Okamoto et al., 2009). However, these mice develop 
resistance to excitotoxicity with age (Graham et al., 2009), and those studies were performed in vulnerable mice. Thus, it is likely that increased extra-synaptic NMDARs during excitotoxicity-sensitive stages might increase $\mathrm{STEP}_{61}$ cleavage to $\mathrm{STEP}_{33}$ enabling higher activation of p38 than in wild-type mice. In contrast, in resistant mice other mechanisms should regulate striatal cell survival in response to excitotoxicity and, according with our findings, STEP regulation of ERK activity seems to play an important role (Saavedra et al., 2011).
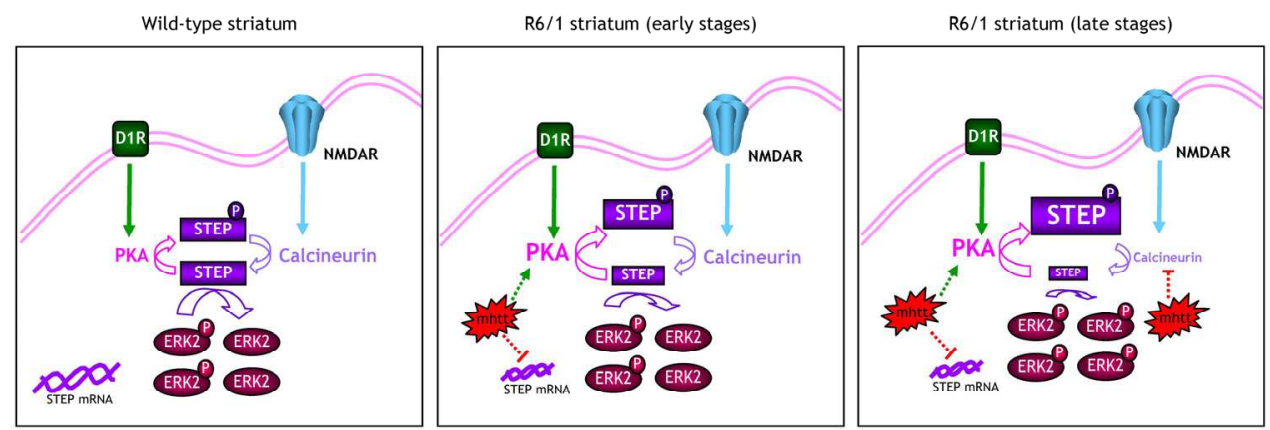

Fig. 4. Regulation of STEP levels and activity in the R6/1 mouse striatum during the progression of the disease. The presence of mhtt in the striatum alters this system at different levels: (1) At early stages mhtt induces a down-regulation of STEP mRNA and protein levels, and a dysregulation of the PKA pathway that correlates with increased STEP phosphorylation. (2) At late stages, calcineurin activity is also reduced further inactivating STEP with a consequent increase of pERK2 levels (p-p38 levels and possibly other nonanalyzed STEP targets). Decreased STEP activity, through the regulation of its targets, could be involved in the development of resistance to excitotoxicity in R6/1 mice striatum.

(scheme from Saavedra et al., 2011).

STEP has recently been implicated in the etiology of Alzheimer's Disease (Kurup et al., 2010; Snyder et al., 2005; Y. Zhang et al., 2010) but the alterations in the STEP pathway found in HD mouse models are specific because STEP protein levels and activity, in contrast to that observed in Alzheimer's Disease, are reduced in HD (Saavedra et al., 2011). Since the genetic reduction of STEP levels reverses cognitive and cellular deficits in Alzheimer's Disease mice (Y. Zhang et al., 2010), the modulation of STEP levels might be a good therapeutic strategy in HD. Nevertheless, the possibility of restoring STEP expression in HD is presently hampered by the lack of data about the regulation of STEP gene expression.

\subsection{MAP kinase phosphatases (MKPs)}

MKPs are intracellular dual Tyr phosphatases with an expression restricted to different subcellular compartments (S. Paul \& Lombroso, 2003). Some of these MKPs, such as MKP-1, $-2,-3$ and $-X$, have been shown to be expressed in the brain with a specific distribution and different substrate preferences. MKP-1 is expressed in the cortex, thalamus, striatum and cerebellum with the following substrate specificity: p38>JNK/SAPK >>ERK (Boschert et al., 1998; Franklin \& Kraft, 1997; Misra-Press et al., 1995; Takaki et al., 2001). MKP-2 is localized in the prefrontal cortex, hippocampus and cerebellum and inactivates ERK and JNK/SAPK 
with the same specificity, but it can also act on p38 (Chu et al., 1996; Dwivedi et al., 2001; Groom et al., 1996; Misra-Press et al., 1995). MKP-3 is detected in the cerebral cortex, striatum and hippocampus acting preferentially on ERK, but it can also inactivate JNK/SAPK and p38 with the same specificity (Boschert et al., 1998; Muda et al., 1996a,b; Takaki et al., 2001). Finally, MKP-X is expressed throughout the brain and acts preferentially on ERK, although it can also dephosphorylate p38 (Boschert et al., 1998; Dowd et al., 1998; Muda et al., 1996b; Shin et al., 1997).

Although they are expressed in the brain, their role in neuronal function is not well established. MKP-1 increases in rat brain after limbic epilepsy (Gass et al., 1996) and, together with MKP-3, upon cerebral hypoxia in neuronal nuclei of newborn piglets (Mishra \& Delivoria-Papadopoulos, 2004). Moreover, both MKP-1 and -3 play important roles in neural plastic modifications after drug exposure (Takaki et al., 2001), whereas MKP-2 is increased in postmortem brains of suicide subjects with major depression (Dwivedi et al., 2001). Recently, it has been shown that MKP-1 controls axon branching of cortical neurons in response to the trophic factor BDNF (Jeanneteau et al., 2010). In addition, in PC12 cells, oxidative stress and hypoxia increase MPK-1 expression, while trophic factor treatment upregulates both MKP-1 and -3 (Camps et al., 1998; Keyse \& Emslie, 1992; Seta et al., 2001). Thus, regulation of MPKs seems to be important not only after brain injury, but also during development.

In a stable PC12 cell line expressing truncated mhtt with $118 \mathrm{Q}, \mathrm{Z}$. L. Wu and colleagues (2002) showed that MKP-1 and -3 mRNA levels, and MKP-1 protein levels, were increased at different time points after mhtt expression. In good correlation with changes in MKPs levels, they observed a substantial reduction of ERK1/2 phosphorylation. Interestingly, treatment with sodium orthovanadate and bp V (pic), two general Tyr phosphatase inhibitors, rescues cells from polyQ-induced cell death suggesting that these phosphatases are involved in mhtt-induced toxicity (Z. L. Wu et al., 2002). In HEK 293 cells transfected with NR1/NR2B and htt containing 138Q, MKP-2 has been shown to be reduced in the soluble fraction and increased in the particulate-derived fraction when compared with cells expressing htt with 15Q (Fan et al., 2008). However, the mechanism underlying this redistribution and the physiological significance of this event are presently unknown.

\section{Conclusion}

Understanding the pathways by which mhtt causes neuronal dysfunction and death is essential to develop efficient treatments for HD. Great progress has been made over the last years in highlighting the molecular mechanisms affected by mhtt. Here, we have reviewed the existing data about changes in the expression and regulation of phosphatases in HD models and human HD brain. From these results, it is becoming increasingly clear that alterations in phosphatases are involved in the pathogenesis of HD. So far, the phosphatases analyzed participate in the regulation of excitotoxicity and neuronal survival (through the regulation of the PI3K/Akt pathway, ERK2 and/or htt phosphorylation). In mouse models, most of them are decreased, which seems to be a compensatory mechanism induced in response to mhtt expression in order to prevent neuronal cell death. However, how this might translate to humans is still unknown as we cannot follow the disease from the beginning, and analysis of phosphatase levels and activity can be performed only at late stages of the disease. We believe that the regulation of phosphatases is a new and promising 
approach to treat HD. Therefore, our future challenge is to develop novel tools to treat HD based on these findings. In addition, phosphatases are also involved in the pathogenesis of other neurodegenerative disorders, and ongoing investigations of disease mechanisms in HD can also provide new therapeutic approaches to Parkinson's or Alzheimer's Diseases.

\section{Acknowledgements}

Research in our group is supported by Fondo de Investigaciones Sanitarias (Instituto de Salud Carlos III, PI10/01072 to E.P.-N.), Ministerio de Educación y Ciencia (Grant SAF200804360 to J.A.), and Generalitat de Catalunya (group of excellence; Grant 2009SGR-00326). A.S. is supported by Ministerio de Ciencia e Innovación, Juan de la Cierva subprograme, Spain (JCI-2010-08207).

\section{References}

Alessi D. R., James S. R., Downes C. P., Holmes A. B., Gaffney P. R., Reese C. B. \& Cohen P. (1997) Characterization of a 3-phosphoinositide-dependent protein kinase which phosphorylates and activates protein kinase Balpha. Current Biology, Vol. 7, No. 4, pp. 261-269, ISSN 0960-9822

Alonso A., Sasin J., Bottini N., Friedberg I., Osterman A., Godzik A., Hunter T., Dixon J. \& Mustelin T. (2004) Protein tyrosine phosphatases in the human genome. Cell, Vol. 117, No. 6, pp. 699-711, ISSN 0092-8674

Amadio M., Battaini F. \& Pascale A. (2006) The different facets of protein kinases C: old and new players in neuronal signal transduction pathways. Pharmacological Research, Vol. 54, No. 5, pp. 317-325, ISSN 1043-6618

Andersen J. N., Jansen P. G., Echwald S. M., Mortensen O. H., Fukada T., Del Vecchio R., Tonks N. K. \& Moller N. P. (2004) A genomic perspective on protein tyrosine phosphatases: gene structure, pseudogenes, and genetic disease linkage. FASEB Journal, Vol. 18, No. 1, pp. 8-30, ISSN 0892-6638

Andre V. M., Cepeda C. \& Levine M. S. (2010) Dopamine and glutamate in Huntington's disease: A balancing act. CNS Neuroscience \& Therapeutics, Vol. 16, No. 3, pp. 163178, ISSN 1755-5930

Ankarcrona M., Dypbukt J. M., Orrenius S. \& Nicotera P. (1996) Calcineurin and mitochondrial function in glutamate-induced neuronal cell death. FEBS Letters, Vol. 394, No. 3, pp. 321-324, ISSN 0014-5793

Anne S. L., Saudou F. \& Humbert S. (2007) Phosphorylation of huntingtin by cyclindependent kinase 5 is induced by DNA damage and regulates wild-type and mutant huntingtin toxicity in neurons. Journal of Neuroscience, Vol. 27, No. 27, pp. 7318-7328, ISSN 0270-6474

Atwal R. S., Desmond C. R., Caron N., Maiuri T., Xia J., Sipione S. \& Truant R. (2011) Kinase inhibitors modulate huntingtin cell localization and toxicity. Nature Chemical Biology, Vol. 7, No. 7, pp. 453-460, ISSN 1552-4450

Bayascas J. R. \& Alessi D. R. (2005) Regulation of Akt/PKB Ser473 phosphorylation. Molecular Cell, Vol. 18, No. 2, pp. 143-145, ISSN 1097-2765

Beals C. R., Clipstone N. A., Ho S. N. \& Crabtree G. R. (1997) Nuclear localization of NF-ATc by a calcineurin-dependent, cyclosporin-sensitive intramolecular interaction. Genes E Development, Vol. 11, No. 7, pp. 824-834, ISSN 0890-9369 
Boschert U., Dickinson R., Muda M., Camps M. \& Arkinstall S. (1998) Regulated expression of dual specificity protein phosphatases in rat brain. Neuroreport, Vol. 9, No. 18, pp. 4081-4086, ISSN 0959- 4965

Boulanger L. M., Lombroso P. J., Raghunathan A., During M. J., Wahle P. \& Naegele J. R. (1995) Cellular and molecular characterization of a brain-enriched protein tyrosine phosphatase. Journal of Neuroscience, Vol. 15, No. 2, pp. 1532-1544, ISSN 0270-6474

Braithwaite S. P., Paul S., Nairn A. C. \& Lombroso P. J. (2006a) Synaptic plasticity: one STEP at a time. Trends in Neuroscience, Vol. 29, No. 8, pp. 452-458, ISSN 0166-2236

Braithwaite S. P., Adkisson M., Leung J., Nava A., Masterson B., Urfer R., Oksenberg D. \& Nikolich K. (2006b) Regulation of NMDA receptor trafficking and function by striatal-enriched tyrosine phosphatase (STEP). European Journal of Neuroscience, Vol. 23, No. 11, pp. 2847-2856, ISSN 0953-816X

Brazil D. P. \& Hemmings B. A. (2001) Ten years of protein kinase B signalling: a hard Akt to follow. Trends in Biochemical Sciences, Vol. 26, No. 11, pp. 657-664, ISSN 0968-0004

Brognard J. \& Newton A. C. (2008) PHLiPPing the switch on Akt and protein kinase C signaling. Trends in Endocrinology and Metabolism, Vol. 19, No. 6, pp. 223-230, ISSN 1043-2760

Brognard J., Sierecki E., Gao T. \& Newton A. C. (2007) PHLPP and a second isoform, PHLPP2, differentially attenuate the amplitude of Akt signaling by regulating distinct Akt isoforms. Molecular Cell, Vol. 25, No. 6, pp. 917-931, ISSN 1097-2765

Bult A., Zhao F., Dirkx R., Jr., Raghunathan A., Solimena M. \& Lombroso P. J. (1997) STEP: a family of brain-enriched PTPs. Alternative splicing produces transmembrane, cytosolic and truncated isoforms. European Journal of Cell Biology, Vol. 72, No. 4, pp. 337-344, ISSN 0171-9335

Butcher S. P., Henshall D. C., Teramura Y., Iwasaki K. \& Sharkey J. (1997) Neuroprotective actions of FK506 in experimental stroke: in vivo evidence against an antiexcitotoxic mechanism. Journal of Neuroscience, Vol. 17, No. 18, pp. 6939-6946, ISSN 0270-6474

Calleja V., Alcor D., Laguerre M., Park J., Vojnovic B., Hemmings B. A., Downward J., Parker P. J. \& Larijani B. (2007) Intramolecular and intermolecular interactions of protein kinase B define its activation in vivo. PLoS Biology, Vol. 5, No. 4, pp. e95, ISSN 1544-9173

Camps M., Chabert C., Muda M., Boschert U., Gillieron C. \& Arkinstall S. (1998) Induction of the mitogen-activated protein kinase phosphatase MKP3 by nerve growth factor in differentiating PC12. FEBS Letters, Vol. 425, No. 2, pp. 271-276, ISSN 0014-5793

Canals J. M., Pineda J. R., Torres-Peraza J. F., Bosch M., Martin-Ibanez R., Munoz M. T., Mengod G., Ernfors P. \& Alberch J. (2004) Brain-derived neurotrophic factor regulates the onset and severity of motor dysfunction associated with enkephalinergic neuronal degeneration in Huntington's disease. Journal of Neuroscience, Vol. 24, No. 35, pp. 7727-7739, ISSN 0270-6474

Cereghetti G. M., Stangherlin A., Martins d. B., Chang C. R., Blackstone C., Bernardi P. \& Scorrano L. (2008) Dephosphorylation by calcineurin regulates translocation of Drp1 to mitochondria. Proceedings of the National Academy of Sciences USA, Vol. 105, No. 41, pp. 15803-15808, ISSN 0027-8424 
Ceulemans H. \& Bollen M. (2004) Functional diversity of protein phosphatase-1, a cellular economizer and reset button. Physiological Reviews, Vol. 84, No. 1, pp. 1-39, ISSN 0031-9333

Choi Y. S., Lin S. L., Lee B., Kurup P., Cho H. Y., Naegele J. R., Lombroso P. J. \& Obrietan K. (2007) Status epilepticus-induced somatostatinergic hilar interneuron degeneration is regulated by striatal enriched protein tyrosine phosphatase. Journal of Neuroscience, Vol. 27, No. 11, pp. 2999-3009, ISSN 0270-6474

Chong Z. Z., Li F. \& Maiese K. (2005) Activating Akt and the brain's resources to drive cellular survival and prevent inflammatory injury. Histology and Histopathology, Vol. 20, No. 1, pp. 299-315, ISSN 0213- 3911

Chu Y., Solski P. A., Khosravi-Far R., Der C. J. \& Kelly K. (1996) The mitogen-activated protein kinase phosphatases PAC1, MKP-1, and MKP-2 have unique substrate specificities and reduced activity in vivo toward the ERK2 sevenmaker mutation. Journal of Biological Chemistry, Vol. 271, No. 11, pp. 6497-6501, ISSN 0021-9258

Chun J. T., Crispino M. \& Tocco G. (2004) The dual response of protein kinase Fyn to neural trauma: early induction in neurons and delayed induction in reactive astrocytes. Experimental Neurology, Vol. 185, No. 1, pp. 109-119, ISSN 0014-4886

Cohen P. \& Nimmo G. A. (1978) The purification and characterization of protein phosphatase inhibitor-1 from rabbit skeletal muscle. Biochemical Society Transactions, Vol. 6, No. 1, pp. 17-20, ISSN 0300-5127

Cohen P. T. (2002) Protein phosphatase 1 - targeted in many directions. Journal of Cell Science, Vol. 115, Pt 2, pp. 241-256, ISSN 0021-9533

Colin E., Zala D., Liot G., Rangone H., Borrell-Pages M., Li X. J., Saudou F. \& Humbert S. (2008) Huntingtin phosphorylation acts as a molecular switch for anterograde/retrograde transport in neurons. EMBO Journal, Vol. 27, No. 15, pp. 2124-2134, ISSN 0261-4189

Costa V., Giacomello M., Hudec R., Lopreiato R., Ermak G., Lim D., Malorni W., Davies K. J., Carafoli E. \& Scorrano L. (2010) Mitochondrial fission and cristae disruption increase the response of cell models of Huntington's disease to apoptotic stimuli. EMBO Molecular Medicine, Vol. 2, No. 12, pp. 490-503, ISSN 1757-4676

Dawson T. M., Steiner J. P., Dawson V. L., Dinerman J. L., Uhl G. R. \& Snyder S. H. (1993) Immunosuppressant FK506 enhances phosphorylation of nitric oxide synthase and protects against glutamate neurotoxicity. Proceedings of the National Academy of Sciences USA, Vol. 90, No. 21, pp. 9808-9812, ISSN 0027-8424

Deb I., Poddar R. \& Paul S. (2011) Oxidative stress-induced oligomerization inhibits the activity of the non-receptor tyrosine phosphatase STEP61. Journal of Neurochemistry, Vol. 116, No. 6, pp. 1097-1111, ISSN 0022-3042

Desplats P. A., Kass K. E., Gilmartin T., Stanwood G. D., Woodward E. L., Head S. R., Sutcliffe J. G. \& Thomas E. A. (2006) Selective deficits in the expression of striatalenriched mRNAs in Huntington's disease. Journal of Neurochemistry, Vol. 96, No. 3, pp. 743-757, ISSN 0022-3042

Diaz-Hernandez M., Torres-Peraza J., Salvatori-Abarca A., Moran M. A., Gomez-Ramos P., Alberch J. \& Lucas J. J. (2005) Full motor recovery despite striatal neuron loss and formation of irreversible amyloid-like inclusions in a conditional mouse model of Huntington's disease. Journal of Neuroscience, Vol. 25, No. 42, pp. 9773-9781, ISSN 0270-6474 
Dowd S., Sneddon A. A. \& Keyse S. M. (1998) Isolation of the human genes encoding the pyst1 and Pyst2 phosphatases: characterisation of Pyst2 as a cytosolic dual-specificity MAP kinase phosphatase and its catalytic activation by both MAP and SAP kinases. Journal of Cell Science, Vol. 111 (Pt 22), No. pp. 3389-3399, ISSN 0021-9533

Ducruet A. P., Vogt A., Wipf P. \& Lazo J. S. (2005) Dual specificity protein phosphatases: therapeutic targets for cancer and Alzheimer's disease. Annual Review of Pharmacology and Toxicology, Vol. 45, No. pp. 725-750, ISSN 0362-1642

Dutil E. M., Toker A. \& Newton A. C. (1998) Regulation of conventional protein kinase C isozymes by phosphoinositide-dependent kinase 1 (PDK-1). Current Biology, Vol. 8 , No. 25, pp. 1366-1375, ISSN 0960-9822

Dwivedi Y., Rizavi H. S., Roberts R. C., Conley R. C., Tamminga C. A. \& Pandey G. N. (2001) Reduced activation and expression of ERK1/2 MAP kinase in the post-mortem brain of depressed suicide subjects. Journal of Neurochemistry, Vol. 77, No. 3, pp. 916-928, ISSN 0022-3042

Ehrnhoefer D. E., Sutton L. \& Hayden M. R. (2011) Small Changes, Big Impact: Posttranslational Modifications and Function of Huntingtin in Huntington Disease. Neuroscientist, Vol. No. pp. ISSN 1073-8584

Ensslen-Craig S. E. \& Brady-Kalnay S. M. (2004) Receptor protein tyrosine phosphatases regulate neural development and axon guidance. Developmental Biology, Vol. 275, No. 1, pp. 12-22, ISSN 0012-1606

Ermak G., Hench K. J., Chang K. T., Sachdev S. \& Davies K. J. (2009) Regulator of calcineurin (RCAN1-1L) is deficient in Huntington disease and protective against mutant huntingtin toxicity in vitro. Journal of Biological Chemistry, Vol. 284, No. 18, pp. 11845-11853, ISSN 0021-9258

Eto M., Senba S., Morita F. \& Yazawa M (1997) Molecular cloning of a novel phosphorylation-dependent inhibitory protein of protein phosphatase-1 (CPI17) in smooth muscle: its specific localization in smooth muscle. FEBS Letters, Vol. 410, No. 2-3, pp. 356-360, ISSN 0014-5793

Fan M. M. \& Raymond L. A. (2007) N-methyl-D-aspartate (NMDA) receptor function and excitotoxicity in Huntington's disease. Progress in Neurobiology, Vol. 81, No. 5-6, pp. 272-293, ISSN 0301-0082

Fan M. M., Zhang H., Hayden M. R., Pelech S. L. \& Raymond L. A. (2008) Protective upregulation of CK2 by mutant huntingtin in cells co-expressing NMDA receptors. Journal of Neurochemistry, Vol. 104, No. 3, pp. 790-805, ISSN 0022-3042

Foulkes J. G. \& Cohen P. (1980) The regulation of glycogen metabolism. Purification and properties of protein phosphatase inhibitor-2 from rabbit skeletal muscle. European Journal of Biochemistry, Vol. 105, No. 1, pp. 195-203, ISSN 0014-2956

Franklin C. C. \& Kraft A.S. (1997) Conditional expression of the mitogen-activated protein kinase (MAPK) phosphatase MKP-1 preferentially inhibits p38 MAPK and stressactivated protein kinase in U937 cells. Journal of Biological Chemistry, Vol. 272, No. 27, pp. 16917-16923, ISSN 0021-9258

Gafni J., Hermel E., Young J. E., Wellington C. L., Hayden M. R. \& Ellerby L. M. (2004) Inhibition of calpain cleavage of huntingtin reduces toxicity: accumulation of calpain/caspase fragments in the nucleus. Journal of Biological Chemistry, Vol. 279, No. 19, pp. 20211-20220, ISSN 0021-9258 
Gao T., Furnari F. \& Newton A. C. (2005) PHLPP: a phosphatase that directly dephosphorylates Akt, promotes apoptosis, and suppresses tumor growth. Molecular Cell, Vol. 18, No. 1, pp. 13-24, ISSN 1097-2765

Gao T., Brognard J. \& Newton A. C. (2008) The phosphatase PHLPP controls the cellular levels of protein kinase C. Journal of Biological Chemistry, Vol. 283, No. 10, pp. 63006311, ISSN 0021-9258

Garcia-Martinez J. M., Perez-Navarro E., Xifro X., Canals J. M., Diaz-Hernandez M., Trioulier Y., Brouillet E., Lucas J. J. \& Alberch J. (2007) BH3-only proteins Bid and Bim(EL) are differentially involved in neuronal dysfunction in mouse models of Huntington's disease. Journal of Neuroscience Research, Vol. 85, No. 12, pp. 2756-2769, ISSN 0360-4012

Garcia A., Cayla X., Guergnon J., Dessauge F., Hospital V., Rebollo M. P., Fleischer A. \& Rebollo A. (2003) Serine/threonine protein phosphatases PP1 and PP2A are key players in apoptosis. Biochimie, Vol. 85, No. 8, pp. 721-726, ISSN 0300-9084

Gass P., Eckhardt A., Schroder H., Bravo R. \& Herdegen T. (1996) Transient expression of the mitogen-activated protein kinase phosphatase MKP-1 (3CH134/ERP1) in the rat brain after limbic epilepsy. Brain Research Molecular Brain Research, Vol. 41, No. 1-2, pp. 74-80, ISSN 0169-328X

Gee C. E. \& Mansuy I. M. (2005) Protein phosphatases and their potential implications in neuroprotective processes. Cellular and Molecular Life Sciences, Vol. 62, No. 10, pp. 1120-1130, ISSN 1420-682X

Goebel-Goody S. M., Davies K. D., Alvestad Linger R. M., Freund R. K. \& Browning M. D. (2009) Phospho-regulation of synaptic and extrasynaptic N-methyl-d-aspartate receptors in adult hippocampal slices. Neuroscience, Vol. 158, No. 4, pp. 1446-1459, ISSN 0306-4522

Goto S., Matsukado Y., Miyamoto E. \& Yamada M. (1987) Morphological characterization of the rat striatal neurons expressing calcineurin immunoreactivity. Neuroscience, Vol. 22, No. 1, pp. 189-201, ISSN 0306-4522

Graham R. K., Pouladi M. A., Joshi P., Lu G., Deng Y., Wu N. P., Figueroa B. E., Metzler M., Andre V. M., Slow E. J., Raymond L., Friedlander R., Levine M. S., Leavitt B. R. \& Hayden M. R. (2009) Differential susceptibility to excitotoxic stress in YAC128 mouse models of Huntington disease between initiation and progression of disease. Journal of Neuroscience, Vol. 29, No. 7, pp. 2193-2204, ISSN 0270-6474

Groom L. A., Sneddon A. A., Alessi D. R., Dowd S. \& Keyse S. M. (1996) Differential regulation of the MAP, SAP and RK/p38 kinases by Pyst1, a novel cytosolic dualspecificity phosphatase. EMBO Journal Vol. 15, No. 14, pp. 3621-3632, ISSN 02614189

Guertin D. A., Stevens D. M., Thoreen C. C., Burds A. A., Kalaany N. Y., Moffat J., Brown M., Fitzgerald K. J. \& Sabatini D. M. (2006) Ablation in mice of the mTORC components raptor, rictor, or mLST8 reveals that mTORC2 is required for signaling to Akt-FOXO and PKCalpha, but not S6K1. Developmental Cell, Vol. 11, No. 6, pp. 859-871, ISSN 1534-5807

Han I., You Y., Kordower J. H., Brady S. T. \& Morfini G. A. (2010) Differential vulnerability of neurons in Huntington's disease: the role of cell type-specific features. Journal of Neurochemistry, Vol. 113, No. 5, pp. 1073-1091, ISSN 0022-3042 
Hansson O., Petersen A., Leist M., Nicotera P., Castilho R. F. \& Brundin P. (1999) Transgenic mice expressing a Huntington's disease mutation are resistant to quinolinic acidinduced striatal excitotoxicity. Proceedings of the National Academy of Sciences USA, Vol. 96, No. 15, pp. 8727-8732, ISSN 0027-8424

Hansson O., Guatteo E., Mercuri N. B., Bernardi G., Li X. J., Castilho R. F. \& Brundin P. (2001) Resistance to NMDA toxicity correlates with appearance of nuclear inclusions, behavioural deficits and changes in calcium homeostasis in mice transgenic for exon 1 of the huntington gene. European Journal of Neuroscience, Vol. 14, No. 9, pp. 1492-1504, ISSN 0953-816X

Hernandez-Espinosa D. \& Morton A. J. (2006) Calcineurin inhibitors cause an acceleration of the neurological phenotype in a mouse transgenic for the human Huntington's disease mutation. Brain Research Bulletin Vol. 69, No. 6, pp. 669-679, ISSN 0361-9230

Herradon G. \& Ezquerra L. (2009) Blocking receptor protein tyrosine phosphatase beta/zeta: a potential therapeutic strategy for Parkinson's disease. Current Medicinal Chemistry, Vol. 16, No. 25, pp. 3322-3329, ISSN 0929-8673

Hodges A., Strand A. D., Aragaki A. K., Kuhn A., Sengstag T., Hughes G., Elliston L. A., Hartog C., Goldstein D. R., Thu D., Hollingsworth Z. R., Collin F., Synek B., Holmans P. A., Young A. B., Wexler N. S., Delorenzi M., Kooperberg C., Augood S. J., Faull R. L., Olson J. M., Jones L. \& Luthi-Carter R. (2006) Regional and cellular gene expression changes in human Huntington's disease brain. Human Molecular Genetics, Vol. 15, No. 6, pp. 965-977, ISSN 0964-6906

Humbert S., Bryson E. A., Cordelieres F. P., Connors N. C., Datta S. R., Finkbeiner S., Greenberg M. E., Saudou F. (2002) The IGF-1/Akt pathway is neuroprotective in Huntington's disease and involves Huntingtin phosphorylation by Akt. Developmental Cell, Vol. 2, No. 6, pp 831-837, ISSN 1534-5807

Iqbal K. \& Grundke-Iqbal I. (2007) Developing pharmacological therapies for Alzheimer disease. Cellular and Molecular Life Sciences, Vol. 64, No. 17, pp. 2234-2244, ISSN 1420-682X

Jackson T. C., Rani A., Kumar A. \& Foster T. C. (2009) Regional hippocampal differences in AKT survival signaling across the lifespan: implications for CA1 vulnerability with aging. Cell Death \& Differentiation, Vol. 16, No. 3, pp. 439-448, ISSN 1350-9047

Jackson T. C., Verrier J. D., Semple-Rowland S., Kumar A. \& Foster T. C. (2010) PHLPP1 splice variants differentially regulate AKT and PKCalpha signaling in hippocampal neurons: characterization of PHLPP proteins in the adult hippocampus. Journal of Neurochemistry, Vol. 115, No. 4, pp. 941-955, ISSN 0022-3042

Jakel R. J. \& Maragos W. F. (2000) Neuronal cell death in Huntington's disease: a potential role for dopamine. Trends in Neurosciences, Vol. 23, No. 6, pp. 239-245, ISSN 01662236

Jarabek B. R., Yasuda R. P. \& Wolfe B. B. (2004) Regulation of proteins affecting NMDA receptor-induced excitotoxicity in a Huntington's mouse model. Brain, Vol. 127, Pt 3, pp. 505-516, ISSN 0006-8950

Jeanneteau F., Deinhardt K., Miyoshi G., Bennett A. M. \& Chao M. V. (2010) The MAP kinase phosphatase MKP-1 regulates BDNF-induced axon branching. Nature Neuroscience, Vol. 13, No. 11, pp. 1373-1379, ISSN 1097-6256 
Jin Y. N. \& Johnson G. V. (2010) The interrelationship between mitochondrial dysfunction and transcriptional dysregulation in Huntington disease. Journal of Bioenergetics and Biomembranes, Vol. 42, No. 3, pp. 199-205, ISSN 0145-479X

Kerr F., Rickle A., Nayeem N., Brandner S., Cowburn R. F. \& Lovestone S. (2006) PTEN, a negative regulator of PI3 kinase signalling, alters tau phosphorylation in cells by mechanisms independent of GSK-3. FEBS Letters, Vol. 580, No. 13, pp. 3121-3128, ISSN 0014-5793

Keyse S. M. \& Emslie E. A. (1992) Oxidative stress and heat shock induce a human gene encoding a protein-tyrosine phosphatase. Nature, Vol. 359, No. 6396, pp. 644-647, ISSN 0028-0836

Klumpp S. \& Krieglstein J. (2002) Serine/threonine protein phosphatases in apoptosis. Current Opinion in Pharmacology, Vol. 2, No. 4, pp. 458-462, ISSN 1471-4892

Kurup P., Zhang Y., Xu J., Venkitaramani D. V., Haroutunian V., Greengard P., Nairn A. C. \& Lombroso P. J. (2010) Abeta-mediated NMDA receptor endocytosis in Alzheimer's disease involves ubiquitination of the tyrosine phosphatase STEP61. Journal of Neuroscience, Vol. 30, No. 17, pp. 5948-5957, ISSN 0270-6474

Landwehrmeyer G. B., Standaert D. G., Testa C. M., Penney J. B. Jr. \& Young A. B. (1995) NMDA receptor subunit mRNA expression by projection neurons and interneurons in rat striatum. Journal of Neuroscience, Vol. 15, No. 7, pp. 5297-5307, ISSN 0270-6474

Laube B., Kuhse J. \& Betz H. (1998) Evidence for a tetrameric structure of recombinant NMDA receptors. Journal of Neuroscience, Vol. 18, No. 8, pp. 2954-2961, ISSN 02706474

Le Good J. A., Ziegler W. H., Parekh D. B., Alessi D. R., Cohen P. \& Parker P. J. (1998) Protein kinase $\mathrm{C}$ isotypes controlled by phosphoinositide 3-kinase through the protein kinase PDK1. Science, Vol. 281, No. 3585, pp. 2042-2045, ISSN 0036-8075

Lee G., Thangavel R., Sharma V. M., Litersky J. M., Bhaskar K., Fang S. M., Do L. H., Andreadis A., Van Hoesen G. \& Ksiezak-Reding H. (2004) Phosphorylation of tau by fyn: implications for Alzheimer's disease. Journal of Neuroscience, Vol. 24, No. 9, pp. 2304-2312, ISSN 0270-6474

Liao Y. \& Hung M. C. (2010) Physiological regulation of Akt activity and stability. American Journal of Translational Research, Vol. 2, No. 1, pp. 19-42, ISSN 1943-8141

Lievens J. C., Woodman B., Mahal A. \& Bates G. P. (2002) Abnormal phosphorylation of synapsin I predicts a neuronal transmission impairment in the R6/2 Huntington's disease transgenic mice. Molecular and Cellular Neuroscience, Vol. 20, No. 4, pp. 638648, ISSN 1044-7431

Liu F., Liang Z. \& Gong C. X. (2006) Hyperphosphorylation of tau and protein phosphatases in Alzheimer disease. Panminerva Medica, Vol. 48, No. 2, pp. 97-108, ISSN 0031-0808

Liu J., Stevens P. D. \& Gao T. (2011) mTOR-dependent regulation of PHLPP expression controls the rapamycin sensitivity in cancer cells. Journal of Biological Chemistry, Vol. 286, No. 8, pp. 6510-6520, ISSN 0021-9258

Lombroso P. J., Murdoch G. \& Lerner M. (1991) Molecular characterization of a proteintyrosine-phosphatase enriched in striatum. Proceedings of the National Academy of Sciences USA , Vol. 88, No. 16, pp. 7242-7246, ISSN 0027-8424 
Lou H., Montoya S. E., Alerte T. N., Wang J., Wu J., Peng X., Hong C. S., Friedrich E. E., Mader S. A., Pedersen C. J., Marcus B. S., McCormack A. L., Di Monte D. A., Daubner S. C. \& Perez R. G. (2010) Serine 129 phosphorylation reduces the ability of alpha-synuclein to regulate tyrosine hydroxylase and protein phosphatase 2A in vitro and in vivo. Journal of Biological Chemistry, Vol. 285, No. 23, pp. 17648-17661, ISSN 0021-9258

Luo S., Vacher C., Davies J. E. \& Rubinsztein D. C. (2005) Cdk5 phosphorylation of huntingtin reduces its cleavage by caspases: implications for mutant huntingtin toxicity. Journal of Cell Biology, Vol. 169, No. 4, pp. 647-656, ISSN 0021-9525

Luthi-Carter R., Strand A., Peters N. L., Solano S. M., Hollingsworth Z. R., Menon A. S., Frey A. S., Spektor B. S., Penney E. B., Schilling G., Ross C. A., Borchelt D. R., Tapscott S. J., Young A. B., Cha J. H. \& Olson J. M. (2000) Decreased expression of striatal signaling genes in a mouse model of Huntington's disease. Human Molecular Genetics, Vol. 9, No. 9, pp. 1259-1271, ISSN 0964-6906

Mangiarini L., Sathasivam K., Seller M., Cozens B., Harper A., Hetherington C., Lawton M., Trottier Y., Lehrach H., Davies S. W. \& Bates G. P. (1996) Exon 1 of the HD gene with an expanded CAG repeat is sufficient to cause a progressive neurological phenotype in transgenic mice. Cell, Vol. 87, No. 3, pp. 493-506, ISSN 0092-8674

Mansuy I. M. (2003) Calcineurin in memory and bidirectional plasticity. Biochemical and Biophysical Research Communications, Vol. 311, No. 4, pp. 1195-1208, ISSN: 0006-291X

Mansuy I. M. \& Shenolikar S. (2006) Protein serine/threonine phosphatases in neuronal plasticity and disorders of learning and memory. Trends in Neuroscience, Vol. 29, No. 12, pp. 679-686, ISSN 0166-2236

Martin-Aparicio E., Yamamoto A., Hernandez F., Hen R., Avila J. \& Lucas J. J. (2001) Proteasomal-dependent aggregate reversal and absence of cell death in a conditional mouse model of Huntington's disease. Journal of Neuroscience, Vol. 21, No. 22, pp. 8772-8781, ISSN 0270-6474

McConnell J. L. \& Wadzinski B. E. (2009) Targeting protein serine/threonine phosphatases for drug development. Molecular Pharmacology, Vol. 75, No. 6, pp. 1249-1261, ISSN 0026-895X

Metzler M., Gan L., Mazarei G., Graham R. K., Liu L., Bissada N., Lu G., Leavitt B. R. \& Hayden M. R. (2010) Phosphorylation of huntingtin at Ser421 in YAC128 neurons is associated with protection of YAC128 neurons from NMDA-mediated excitotoxicity and is modulated by PP1 and PP2A. Journal of Neuroscience, Vol. 30, No. 43, pp. 14318-14329, ISSN 0270-6474

Millward T. A., Zolnierowicz S. \& Hemmings B. A. (1999) Regulation of protein kinase cascades by protein phosphatase 2A. Trends in Biochemical Sciences, Vol. 24, No. 5, pp. 186-191, ISSN 0968-0004

Milnerwood A. J. \& Raymond L. A. (2010) Early synaptic pathophysiology in neurodegeneration: insights from Huntington's disease. Trends in Neurosciences, Vol. 33, No. 11, pp. 513-523, ISSN 0166-2236

Milnerwood A. J., Gladding C. M., Pouladi M. A., Kaufman A. M., Hines R. M., Boyd J. D., Ko R. W., Vasuta O. C., Graham R. K., Hayden M. R., Murphy T. H. \& Raymond L. A. (2010) Early increase in extrasynaptic NMDA receptor signaling and expression contributes to phenotype onset in Huntington's disease mice. Neuron, Vol. 65, No. 2, pp. 178-190, ISSN 0896-6273 
Mishra O. P. \& Delivoria-Papadopoulos M. (2004) Effect of hypoxia on protein tyrosine kinase activity in cortical membranes of newborn piglets--the role of nitric oxide. Neuroscience Letters, Vol. 372, No. 1-2, pp. 114-118, ISSN 0304-3940

Misra-Press A., Rim C. S., Yao H., Roberson M. S. \& Stork P. J. (1995) A novel mitogenactivated protein kinase phosphatase. Structure, expression, and regulation. Journal of Biological Chemistry, Vol. 270, No. 24, pp. 14587-14596, ISSN 0021-9258

Muda M., Boschert U., Dickinson R., Martinou J. C., Martinou I., Camps M., Schlegel W. \& Arkinstall S. (1996a) MKP-3, a novel cytosolic protein-tyrosine phosphatase that exemplifies a new class of mitogen-activated protein kinase phosphatase. Journal of Biological Chemistry, Vol. 271, No. 8, pp. 4319-4326, ISSN 0021-9258

Muda M., Theodosiou A., Rodrigues N., Boschert U., Camps M., Gillieron C., Davies K., Ashworth A. \& Arkinstall S. (1996b) The dual specificity phosphatases M3/6 and MKP-3 are highly selective for inactivation of distinct mitogen-activated protein kinases. Journal of Biological Chemistry, Vol. 271, No. 44, pp. 27205-27208, ISSN 00219258

Mukherjee A. \& Soto C. (2011) Role of calcineurin in neurodegeneration produced by misfolded proteins and endoplasmic reticulum stress. Current Opinion in Cell Biology, Vol. 23, No. 2, pp. 223-230, ISSN 0955-0674

Mukherjee S., Poddar R., Deb I. \& Paul S. (2011) Dephosphorylation of specific sites in the KIS domain leads to ubiquitin-mediated degradation of the tyrosine phosphatase STEP. Biochemical Journal, doi:10.1042/BJ20110240, ISSN 0264-6021

Munoz J. J., Tarrega C., Blanco-Aparicio C. \& Pulido R. (2003) Differential interaction of the tyrosine phosphatases PTP-SL, STEP and HePTP with the mitogen-activated protein kinases ERK1/2 and p38alpha is determined by a kinase specificity sequence and influenced by reducing agents. Biochemical Journal, Vol. 372, Pt 1, pp. 193-201, ISSN 0264-6021

Newton A. C. (2003) Regulation of the ABC kinases by phosphorylation: protein kinase $C$ as a paradigm. Biochemical Journal, Vol. 370, Pt 2, pp. 361-371, ISSN 0264-6021

Nguyen T. H., Liu J. \& Lombroso P. J. (2002) Striatal enriched phosphatase 61 dephosphorylates Fyn at phosphotyrosine 420. Journal of Biological Chemistry, Vol. 277, No. 27, pp. 24274-24279, ISSN 0021-9258

Nishi A., Bibb J. A., Matsuyama S., Hamada M., Higashi H., Nairn A. C. \& Greengard P. (2002) Regulation of DARPP-32 dephosphorylation at PKA- and Cdk5-sites by NMDA and AMPA receptors: distinct roles of calcineurin and protein phosphatase2A. Journal of Neurochemistry, Vol. 81, No. 4, pp. 832-841, ISSN 0022-3042

Ohtsuki T., Matsumoto M., Kitagawa K., Mabuchi T., Mandai K., Matsushita K., Kuwabara K., Tagaya M., Ogawa S., Ueda H., Kamada T. \& Yanagihara T. (1996) Delayed neuronal death in ischemic hippocampus involves stimulation of protein tyrosine phosphorylation. American Journal of Physiology, Vol. 271, No. 4 Pt 1, pp. C1085C1097, ISSN 0363-6143

Okamoto S., Pouladi M. A., Talantova M., Yao D., Xia P., Ehrnhoefer D. E., Zaidi R., Clemente A., Kaul M., Graham R. K., Zhang D., Vincent Chen H. S., Tong G., Hayden M. R. \& Lipton S. A. (2009) Balance between synaptic versus extrasynaptic NMDA receptor activity influences inclusions and neurotoxicity of mutant huntingtin. Nature Medicine, Vol. 15, No. 12, pp. 1407-1413, ISSN 1078-8956

Olney J. W. \& Sharpe L. G. (1969) Brain lesions in an infant rhesus monkey treated with monsodium glutamate. Science, Vol. 166, No. 903, pp. 386-388, ISSN 0036-8075 
Oyama T., Goto S., Nishi T., Sato K., Yamada K., Yoshikawa M. \& Ushio Y. (1995) Immunocytochemical localization of the striatal enriched protein tyrosine phosphatase in the rat striatum: a light and electron microscopic study with a complementary DNA-generated polyclonal antibody. Neuroscience, Vol. 69, No. 3, pp. 869-880, ISSN 0306-4522

Ozawa S., Kamiya H. \& Tsuzuki K. (1998) Glutamate receptors in the mammalian central nervous system. Progress in Neurobiology, Vol. 54, No. 5, pp. 581-618, ISSN 03010082

Pardo R., Colin E., Regulier E., Aebischer P., Deglon N., Humbert S. \& Saudou F. (2006) Inhibition of calcineurin by FK506 protects against polyglutamine-huntingtin toxicity through an increase of huntingtin phosphorylation at S421. Journal of Neuroscience, Vol. 26, No. 5, pp. 1635-1645, ISSN 0270-6474

Paul R., Zhang Z. G., Eliceiri B. P., Jiang Q., Boccia A. D., Zhang R. L., Chopp M. \& Cheresh D. A. (2001) Src deficiency or blockade of Src activity in mice provides cerebral protection following stroke. Nature Medicine, Vol. 7, No. 2, pp. 222-227, ISSN 10788956

Paul S. \& Lombroso P. J. (2003) Receptor and nonreceptor protein tyrosine phosphatases in the nervous system. Cellular and Molecular Life Sciences, Vol. 60, No. 11, pp. 24652482, ISSN 1421-682X

Paul S., Nairn A. C., Wang P. \& Lombroso P. J. (2003) NMDA-mediated activation of the tyrosine phosphatase STEP regulates the duration of ERK signaling. Nature Neuroscience, Vol. 6, No. 1, pp. 34-42, ISSN 1097-6256

Paul S., Snyder G. L., Yokakura H., Picciotto M. R., Nairn A. C. \& Lombroso P. J. (2000) The Dopamine/D1 receptor mediates the phosphorylation and inactivation of the protein tyrosine phosphatase STEP via a PKA-dependent pathway. Journal of Neuroscience, Vol. 20, No. 15, pp. 5630-5638, ISSN 0270-6474

Pearce L. R., Komander D. \& Alessi D. R. (2010) The nuts and bolts of AGC protein kinases. Nature Reviews Molecular Cell Biology, Vol. 11, No. 1, pp. 9-22, ISSN 1471-0080

Pelkey K. A., Askalan R., Paul S., Kalia L. V., Nguyen T. H., Pitcher G. M., Salter M. W. \& Lombroso P. J. (2002) Tyrosine phosphatase STEP is a tonic brake on induction of long-term potentiation. Neuron, Vol. 34, No. 1, pp. 127-138, ISSN 0896-6273

Perez-Navarro E., Canals J. M., Gines S. \& Alberch J. (2006) Cellular and molecular mechanisms involved in the selective vulnerability of striatal projection neurons in Huntington's disease. Histology and Histopathology, Vol. 21, No. 11, pp. 1217-1232, ISSN 0213- 3911

Pineda J. R., Pardo R., Zala D., Yu H., Humbert S. \& Saudou F. (2009) Genetic and pharmacological inhibition of calcineurin corrects the BDNF transport defect in Huntington's disease. Molecular Brain, Vol. 2, pp. 33, ISSN 1756-6606

Poddar R., Deb I., Mukherjee S. \& Paul S. (2010) NR2B-NMDA receptor mediated modulation of the tyrosine phosphatase STEP regulates glutamate induced neuronal cell death. Journal of Neurochemistry, Vol. 115, No. 6, pp. 1350-1362, ISSN 0022-3042

Pulido R., Zuniga A. \& Ullrich A. (1998) PTP-SL and STEP protein tyrosine phosphatases regulate the activation of the extracellular signal-regulated kinases ERK1 and ERK2 by association through a kinase interaction motif. EMBO Journal, Vol. 17, No. 24, pp. 7337-7350, ISSN 0261-4189 
Rangone H., Poizat G., Troncoso J., Ross C. A., MacDonald M. E., Saudou F. \& Humbert S. (2004) The serum- and glucocorticoid-induced kinase SGK inhibits mutant huntingtin-induced toxicity by phosphorylating serine 421 of huntingtin. European Journal of Neuroscience, Vol. 19, No. 2, pp. 273-279, ISSN 0953-816X

Ravikumar B., Vacher C., Berger Z., Davies J. E., Luo S., Oroz L. G., Scaravilli F., Easton D. F., Duden R., O'Kane C. J. \& Rubinsztein D. C. (2004) Inhibition of mTOR induces autophagy and reduces toxicity of polyglutamine expansions in fly and mouse models of Huntington disease. Nature Genetics, Vol. 36, No. 6, pp. 585-595, ISSN 1061-4036

Renna M., Jimenez-Sanchez M., Sarkar S. \& Rubinsztein D. C. (2010) Chemical inducers of autophagy that enhance the clearance of mutant proteins in neurodegenerative diseases. Journal of Biological Chemistry, Vol. 285, No. 15, pp. 11061-11067, ISSN 0021-9258

Rosenstock T. R., Duarte A. I. \& Rego A. C. (2010) Mitochondrial-associated metabolic changes and neurodegeneration in Huntington's disease - from clinical features to the bench. Current Drug Targets, Vol. 11, No. 10, pp. 1218-1236, ISSN 1389-4501

Runne H., Regulier E., Kuhn A., Zala D., Gokce O., Perrin V., Sick B., Aebischer P., Deglon N. \& Luthi-Carter R. (2008) Dysregulation of gene expression in primary neuron models of Huntington's disease shows that polyglutamine-related effects on the striatal transcriptome may not be dependent on brain circuitry. Journal of Neuroscience, Vol. 28, No. 39, pp. 9723-9731, ISSN 0270-6474

Saavedra A., Garcia-Martinez J. M., Xifro X., Giralt A., Torres-Peraza J. F., Canals J. M., DiazHernandez M., Lucas J. J., Alberch J. \& Perez-Navarro E. (2010) PH domain leucinerich repeat protein phosphatase 1 contributes to maintain the activation of the PI3K/Akt pro-survival pathway in Huntington's disease striatum. Cell Death $\mathcal{E}$ Differentiation, Vol. 17, No. 2, pp. 324-335, ISSN 1350-9047

Saavedra A., Giralt A., Rue L., Xifro X., Xu J., Ortega Z., Lucas J. J., Lombroso P. J., Alberch J. \& Perez-Navarro E. (2011) Striatal-enriched protein tyrosine phosphatase expression and activity in Huntington's disease: a STEP in the resistance to excitotoxicity. Journal of Neuroscience, Vol. 31, No. 22, pp. 8150-8162, ISSN 0270-6474

Sancak Y., Peterson T. R., Shaul Y. D., Lindquist R. A., Thoreen C. C., Bar-Peled L. \& Sabatini D. M. (2008) The Rag GTPases bind raptor and mediate amino acid signaling to mTORC1. Science, Vol. 320, No. 5882, pp. 1496-1501, ISSN 0036-8075

Sanna P. P., Berton F., Cammalleri M., Tallent M. K., Siggins G. R., Bloom F. E., Francesconi W. (2000) A role for Src kinase in spontaneous epileptiform activity in the CA3 region of the hippocampus. Proceedings of the National Academy of Sciences USA, Vol. 97, No. 15, pp. 8653-8657, ISSN 0027-8424

Sarbassov D. D., Guertin D. A., Ali S. M. \& Sabatini D. M. (2005) Phosphorylation and regulation of Akt/PKB by the rictor-mTOR complex. Science, Vol. 307, No. 5712, pp. 1098-1101, ISSN 0036-8075

Sarbassov D. D., Ali S. M., Kim D. H., Guertin D. A., Latek R. R., Erdjument-Bromage H., Tempst P. \& Sabatini D. M. (2004) Rictor, a novel binding partner of mTOR, defines a rapamycin-insensitive and raptor-independent pathway that regulates the cytoskeleton. Current Biology, Vol. 14, No. 14, pp. 1296-1302, ISSN 0960-9822 
Schilling B., Gafni J., Torcassi C., Cong X., Row R. H., LaFevre-Bernt M. A., Cusack M. P., Ratovitski T., Hirschhorn R., Ross C. A., Gibson B. W. \& Ellerby L. M. (2006) Huntingtin phosphorylation sites mapped by mass spectrometry. Modulation of cleavage and toxicity. Journal of Biological Chemistry, Vol. 281, No. 33, pp. 2368623697, ISSN 0021-9258

Seta K. A., Kim R., Kim H. W., Millhorn D. E. \& Beitner-Johnson D. (2001) Hypoxia-induced regulation of MAPK phosphatase-1 as identified by subtractive suppression hybridization and cDNA microarray analysis. Journal of Biological Chemistry, Vol. 276, No. 48, pp. 44405-44412, ISSN 0021-9258

Shamloo M., Soriano L., Wieloch T., Nikolich K., Urfer R. \& Oksenberg D. (2005) Deathassociated protein kinase is activated by dephosphorylation in response to cerebral ischemia. Journal of Biological Chemistry, Vol. 280, No. 51, pp. 42290-42299, ISSN 0021-9258

Sharma E., Zhao F., Bult A. \& Lombroso P. J. (1995) Identification of two alternatively spliced transcripts of STEP: a subfamily of brain-enriched protein tyrosine phosphatases. Brain Research Molecular Brain Research, Vol. 32, No. 1, pp. 87-93, ISSN 0169-328X

Shehadeh J., Fernandes H. B., Zeron Mullins M. M., Graham R. K., Leavitt B. R., Hayden M. R. \& Raymond L. A. (2006) Striatal neuronal apoptosis is preferentially enhanced by NMDA receptor activation in YAC transgenic mouse model of Huntington disease. Neurobiology of Disease, Vol. 21, No. 2, pp. 392-403, ISSN 0969-9961

Sheppeck J. E., Gauss C. M. \& Chamberlin A. R. (1997) Inhibition of the Ser-Thr phosphatases PP1 and PP2A by naturally occurring toxins. Bioorganic E Medicinal Chemistry, Vol. 5, No. 9, pp. 1739-1750, ISSN 0968-0896

Shi Y. (2009) Serine/threonine phosphatases: mechanism through structure. Cell, Vol. 139, No. 3, pp. 468-484, ISSN 0092-8674

Shibasaki F. \& McKeon F. (1995) Calcineurin functions in $\mathrm{Ca}(2+)$-activated cell death in mammalian cells. Journal of Cell Biology, Vol. 131, No. 3, pp. 735-743, ISSN 0021-9525

Shibasaki F., Hallin U. \& Uchino H. (2002) Calcineurin as a multifunctional regulator. Journal of Biochemistry, Vol. 131, No. 1, pp. 1-15, ISSN 0021-924X

Shields S. M., Ingebritsen T. S. \& Kelly P. T. (1985) Identification of protein phosphatase 1 in synaptic junctions: dephosphorylation of endogenous calmodulin-dependent kinase II and synapse-enriched phosphoproteins. Journal of Neuroscience, Vol. 5, No. 12, pp. 3414-3422, ISSN 0270-6474

Shimizu K., Okada M., Takano A. \& Nagai K. (1999) SCOP, a novel gene product expressed in a circadian manner in rat suprachiasmatic nucleus. FEBS Letters, Vol. 458, No. 3 , pp. 363-369, ISSN 0014-5793

Shimizu K., Okada M., Nagai K. \& Fukada Y. (2003) Suprachiasmatic nucleus circadian oscillatory protein, a novel binding partner of K-Ras in the membrane rafts, negatively regulates MAPK pathway. Journal of Biological Chemistry, Vol. 278, No. 17, pp. 14920-14925, ISSN 0021-9258

Shimizu K., Phan T., Mansuy I. M. \& Storm D. R. (2007) Proteolytic degradation of SCOP in the hippocampus contributes to activation of MAP kinase and memory. Cell, Vol. 128, No. 6, pp. 1219-1229, ISSN 0092-8674

Shin D. Y., Ishibashi T., Choi T. S., Chung E., Chung I. Y., Aaronson S. A. \& Bottaro D. P. (1997) A novel human ERK phosphatase regulates H-ras and v-raf signal transduction. Oncogene, Vol. 14, No. 22, pp. 2633-2639, ISSN 0950-9232 
Snyder E. M., Nong Y., Almeida C. G., Paul S., Moran T., Choi E. Y., Nairn A. C., Salter M. W., Lombroso P. J., Gouras G. K. \& Greengard P. (2005) Regulation of NMDA receptor trafficking by amyloid-beta. Nature Neuroscience, Vol. 8, No. 8, pp. 10511058, ISSN 1097-6256

Song C., Zhang Y., Parsons C. G. \& Liu Y. F. (2003) Expression of polyglutamine-expanded huntingtin induces tyrosine phosphorylation of N-methyl-D-aspartate receptors. Journal of Biological Chemistry, Vol. 278, No. 35, pp. 33364-33369, ISSN 0021-9258

Springer J. E., Azbill R. D., Nottingham S. A. \& Kennedy S. E. (2000) Calcineurin-mediated BAD dephosphorylation activates the caspase-3 apoptotic cascade in traumatic spinal cord injury. Journal of Neuroscience, Vol. 20, No. 19, pp. 7246-7251, ISSN 02706474

Stoof J. C. \& Kebabian J. W. (1981) Opposing roles for D-1 and D-2 dopamine receptors in efflux of cyclic AMP from rat neostriatum. Nature, Vol. 294, No. 5839, pp. 366-368, ISSN 0028-0836

Strack S., Choi S., Lovinger D. M. \& Colbran R. J. (1997) Translocation of autophosphorylated calcium/calmodulin-dependent protein kinase II to the postsynaptic density. Journal of Biological Chemistry, Vol. 272, No. 21, pp. 1346713470, ISSN 0021-9258

Sun Y., Savanenin A., Reddy P. H. \& Liu Y. F. (2001) Polyglutamine-expanded huntingtin promotes sensitization of N-methyl-D-aspartate receptors via post-synaptic density 95. Journal of Biological Chemistry, Vol. 276, No. 27, pp. 24713-24718, ISSN 0021-9258

Takaki M., Ujike H., Kodama M., Takehisa Y., Nakata K. \& Kuroda S. (2001) Two kinds of mitogen-activated protein kinase phosphatases, MKP-1 and MKP-3, are differentially activated by acute and chronic methamphetamine treatment in the rat brain. Journal of Neurochemistry, Vol. 79, No. 3, pp. 679-688, ISSN 0022-3042

Tang T. S., Slow E., Lupu V., Stavrovskaya I. G., Sugimori M., Llinas R., Kristal B. S., Hayden M. R. \& Bezprozvanny I. (2005) Disturbed Ca2+ signaling and apoptosis of medium spiny neurons in Huntington's disease. Proceedings of the National Academy of Sciences USA, Vol. 102, No. 7, pp. 2602-2607, ISSN 0027-8424

Thompson L. M., Aiken C. T., Kaltenbach L. S., Agrawal N., Illes K., Khoshnan A., MartinezVincente M., Arrasate M., O'Rourke J. G., Khashwji H., Lukacsovich T., Zhu Y. Z., Lau A. L., Massey A., Hayden M. R., Zeitlin S. O., Finkbeiner S., Green K. N., LaFerla F. M., Bates G., Huang L., Patterson P. H., Lo D. C., Cuervo A. M., Marsh J. L. \& Steffan J. S. (2009) IKK phosphorylates Huntingtin and targets it for degradation by the proteasome and lysosome. Journal of Cell Biology, Vol. 187, No. 7, pp. 1083-1099, ISSN 0021-9525

Tian Q. \& Wang J. (2002) Role of serine/threonine protein phosphatase in Alzheimer's disease. Neurosignals, Vol. 11, No. 5, pp. 262-269, ISSN 1424-862X

Torres-Peraza J. F., Giralt A., Garcia-Martinez J. M., Pedrosa E., Canals J. M. \& Alberch J. (2008) Disruption of striatal glutamatergic transmission induced by mutant huntingtin involves remodeling of both postsynaptic density and NMDA receptor signaling. Neurobiology of Disease, Vol. 29, No. 3, pp. 409-421, ISSN 0969-9961

Valjent E., Pascoli V., Svenningsson P., Paul S., Enslen H., Corvol J. C., Stipanovich A., Caboche J., Lombroso P. J., Nairn A. C., Greengard P., Herve D. \& Girault J. A. (2005) Regulation of a protein phosphatase cascade allows convergent dopamine and glutamate signals to activate ERK in the striatum. Proceedings of the National Academy of Sciences USA, Vol. 102, No. 2, pp. 491-496, ISSN 0027-8424 
Walaas S. I. \& Greengard P. (1991) Protein phosphorylation and neuronal function. Pharmacological Reviews, Vol. 43, No. 3, pp. 299-349, ISSN: 0031-6997

Wang H. G., Pathan N., Ethell I. M., Krajewski S., Yamaguchi Y., Shibasaki F., McKeon F., Bobo T., Franke T. F. \& Reed J. C. (1999) Ca2+-induced apoptosis through calcineurin dephosphorylation of BAD. Science, Vol. 284, No. 5412, pp. 339-343, ISSN 0036-8075

Wang L. Y., Orser B. A., Brautigan D. L. \& MacDonald J. F. (1994) Regulation of NMDA receptors in cultured hippocampal neurons by protein phosphatases 1 and 2A. Nature, Vol. 369, No. 6477, pp. 230-232, ISSN 0028-0836

Wang X., Zhong P. \& Yan Z. (2002) Dopamine D4 receptors modulate GABAergic signaling in pyramidal neurons of prefrontal cortex. Journal of Neuroscience, Vol. 22, No. 21, pp. 9185-9193, ISSN 0270-6474

Warby S. C., Chan E. Y., Metzler M., Gan L., Singaraja R. R., Crocker S. F., Robertson H. A. \& Hayden M. R. (2005) Huntingtin phosphorylation on serine 421 is significantly reduced in the striatum and by polyglutamine expansion in vivo. Human Molecular Genetics, Vol. 14, No. 11, pp. 1569-1577, ISSN 0964-6906

Warby S. C., Doty C. N., Graham R. K., Shively J., Singaraja R. R. \& Hayden M. R. (2009) Phosphorylation of huntingtin reduces the accumulation of its nuclear fragments. Molecular and Cellular Neuroscience. Vol. 40, No. 2, pp. 121-127, ISSN 1044-7431

Weir D. W., Sturrock A. \& Leavitt B. R. (2011) Development of biomarkers for Huntington's disease. Lancet Neurology, Vol. 10, No. 6, pp. 573-590, ISSN 1474-4422

Wera S. \& Neyts J. (1994) Calcineurin as a possible new target for treatment of Parkinson's disease. Medical Hypotheses, Vol. 43, No. 3, pp. 132-134, ISSN 0306-9877

Westphal R. S., Tavalin S. J., Lin J. W., Alto N. M., Fraser I. D., Langeberg L. K., Sheng M. \& Scott J. D. (1999) Regulation of NMDA receptors by an associated phosphatase-kinase signaling complex. Science, Vol. 285, No. 5424, pp. 93-96, ISSN 0036-8075

Wood A. M. \& Bristow D. R. (1998) N-methyl-D-aspartate receptor desensitisation is neuroprotective by inhibiting glutamate-induced apoptotic-like death. Journal of Neurochemistry, Vol. 70, No. 2, pp. 677-687, ISSN 0022-3042

Wu H. Y., Tomizawa K., Oda Y., Wei F. Y., Lu Y. F., Matsushita M., Li S. T., Moriwaki A. \& Matsui H. (2004) Critical role of calpain-mediated cleavage of calcineurin in excitotoxic neurodegeneration. Journal of Biological Chemistry, Vol. 279, No. 6, pp. 4929-4940, ISSN 0021-9258

Wu Z. L., O'Kane T. M., Scott R. W., Savage M. J. \& Bozyczko-Coyne D. (2002) Protein tyrosine phosphatases are up-regulated and participate in cell death induced by polyglutamine expansion. Journal of Biological Chemistry, Vol. 277, No. 46, pp. 4420844213, ISSN 0021-9258

Xifro X., Garcia-Martinez J. M., Del Toro D., Alberch J. \& Perez-Navarro E. (2008) Calcineurin is involved in the early activation of NMDA-mediated cell death in mutant huntingtin knock-in striatal cells. Journal of Neurochemistry, Vol. 105, No. 5, pp. 1596-1612, ISSN 0022-3042

Xifro X., Giralt A., Saavedra A., Garcia-Martinez J. M., Diaz-Hernandez M., Lucas J. J., Alberch J. \& Perez-Navarro E. (2009) Reduced calcineurin protein levels and activity in exon-1 mouse models of Huntington's disease: role in excitotoxicity. Neurobiology of Disease, Vol. 36, No. 3, pp. 461-469, ISSN 0969-9961 
Xu J., Kurup P., Zhang Y., Goebel-Goody S. M., Wu P. H., Hawasli A. H., Baum M. L., Bibb J. A. \& Lombroso P. J. (2009) Extrasynaptic NMDA receptors couple preferentially to excitotoxicity via calpain-mediated cleavage of STEP. Journal of Neuroscience, Vol. 29, No. 29, pp. 9330-9343, ISSN 0270-6474

Yamanaka T., Miyazaki H., Oyama F., Kurosawa M., Washizu C., Doi H., Nukina N. (2008) Mutant Huntingtin reduces HSP70 expression through the sequestration of NF-Y transcription factor. EMBO Journal, Vol. 27, No. 6, pp. 827-839., ISSN 0261-4189

Zala D., Colin E., Rangone H., Liot G., Humbert S. \& Saudou F. (2008) Phosphorylation of mutant huntingtin at S421 restores anterograde and retrograde transport in neurons. Human Molecular Genetics, Vol. 17, No. 24, pp. 3837-3846, ISSN 0964-6906

Zeron M. M., Chen N., Moshaver A., Lee A. T., Wellington C. L., Hayden M. R. \& Raymond L. A. (2001) Mutant huntingtin enhances excitotoxic cell death. Molecular and Cellular Neuroscience, Vol. 17, No. 1, pp. 41-53, ISSN 1044-7431

Zeron M. M., Hansson O., Chen N., Wellington C. L., Leavitt B. R., Brundin P., Hayden M. R. \& Raymond L. A. (2002) Increased sensitivity to N-methyl-D-aspartate receptormediated excitotoxicity in a mouse model of Huntington's disease. Neuron, Vol. 33, No. 6, pp. 849-860, ISSN 0896-6273

Zhang Y., Venkitaramani D. V., Gladding C. M., Kurup P., Molnar E., Collingridge G. L. \& Lombroso P. J. (2008) The tyrosine phosphatase STEP mediates AMPA receptor endocytosis after metabotropic glutamate receptor stimulation. Journal of Neuroscience, Vol. 28, No. 42, pp. 10561-10566, ISSN 0270-6474

Zhang Y., Kurup P., Xu J., Carty N., Fernandez S. M., Nygaard H. B., Pittenger C., Greengard P., Strittmatter S. M., Nairn A. C. \& Lombroso P. J. (2010) Genetic reduction of striatal-enriched tyrosine phosphatase (STEP) reverses cognitive and cellular deficits in an Alzheimer's disease mouse model. Proceedings of the National Academy of Sciences USA , Vol. 107, No. 44, pp. 19014-19019, ISSN 0027-8424

Zhang Z. Y. (2002) Protein tyrosine phosphatases: structure and function, substrate specificity, and inhibitor development. Annual Review of Pharmacology and Toxicolology, Vol. 42, No. pp. 209-234, ISSN 0362-1642 


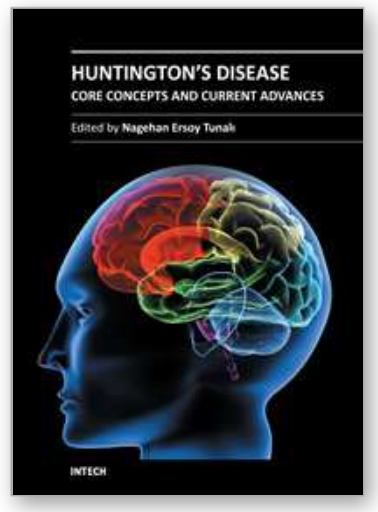

\author{
Huntington's Disease - Core Concepts and Current Advances \\ Edited by Dr Nagehan Ersoy Tunali
}

ISBN 978-953-307-953-0

Hard cover, 554 pages

Publisher InTech

Published online 15, February, 2012

Published in print edition February, 2012

Huntington's Disease is one of the well-studied neurodegenerative conditions, a quite devastating and currently incurable one. It is a brain disorder that causes certain types of neurons to become damaged, causing various parts of the brain to deteriorate and lose their function. This results in uncontrolled movements, loss of intellectual capabilities and behavioural disturbances. Since the identification of the causative mutation, there have been many significant developments in understanding the cellular and molecular perturbations. This book, "Huntington's Disease - Core Concepts and Current Advances", was prepared to serve as a source of up-to-date information on a wide range of issues involved in Huntington's Disease. It will help the clinicians, health care providers, researchers, graduate students and life science readers to increase their understanding of the clinical correlates, genetic aspects, neuropathological findings, cellular and molecular events and potential therapeutic interventions involved in HD. The book not only serves reviewed fundamental information on the disease but also presents original research in several disciplines, which collectively provide comprehensive description of the key issues in the area.

\title{
How to reference
}

In order to correctly reference this scholarly work, feel free to copy and paste the following:

Ana Saavedra, Jordi Alberch and Esther Pérez-Navarro (2012). Don't Take Away My P: Phosphatases as Therapeutic Targets in Huntington's Disease, Huntington's Disease - Core Concepts and Current Advances, Dr Nagehan Ersoy Tunali (Ed.), ISBN: 978-953-307-953-0, InTech, Available from:

http://www.intechopen.com/books/huntington-s-disease-core-concepts-and-current-advances/don-t-takeaway-my-p-phosphatases-as-therapeutic-targets-in-huntington-s-disease

\section{INTECH}

open science / open minds

\section{InTech Europe}

University Campus STeP Ri

Slavka Krautzeka 83/A

51000 Rijeka, Croatia

Phone: +385 (51) 770447

Fax: +385 (51) 686166

www.intechopen.com

\section{InTech China}

Unit 405, Office Block, Hotel Equatorial Shanghai

No.65, Yan An Road (West), Shanghai, 200040, China

中国上海市延安西路65号上海国际贵都大饭店办公楼405单元

Phone: +86-21-62489820

Fax: $+86-21-62489821$ 
(C) 2012 The Author(s). Licensee IntechOpen. This is an open access article distributed under the terms of the Creative Commons Attribution 3.0 License, which permits unrestricted use, distribution, and reproduction in any medium, provided the original work is properly cited. 